\title{
PALYNOMORPH PRESERVATION IN VOLCANICLASTIC ROCKS OF THE MIOCENE TEPOZTLÁN FORMATION (CENTRAL MEXICO) AND IMPLICATIONS FOR PALEOENVIRONMENTAL RECONSTRUCTION
}

\author{
NILS LENHARDT ${ }^{1 *}$, MARK HERRMANN ${ }^{2}$, ANNETTE E. GÖTZ ${ }^{3}$ \\ ${ }^{I}$ Department of Geology, University of Pretoria, Private Bag X20, 0028 Pretoria, South Africa, e-mail: \\ nils.lenhardt@up.ac.za; ${ }^{2}$ BFU GmbH, Büro für Umwelttechnologie, Frankfurter Str. 42, 63571 Gelnhausen, \\ Germany; ${ }^{3}$ Department of Geology, Rhodes University, 6140 Grahamstown, South Africa
}

*Corresponding author.

RRH: PALYNOMORPH PRESERVATION IN VOLCANICLASTIC ROCKS

LRH: LENHARDT ET AL.

Keywords: volcaniclastics, palynomorphs, taphonomy, Miocene, Central Mexico

Published as:

Lenhardt, N., Herrmann, M. \& Götz, A.E. (2013) Palynomorph preservation in volcaniclastic rocks of the Miocene Tepoztlán Formation (Central Mexico) and implications for paleoenvironmental reconstruction. Palaios, 28(10), 710-723. doi: 10.2110/palo.2013.p13-015r.

\begin{abstract}
Palynomorph preservation in sedimentary rocks is strongly affected by various taphonomic factors related to transport, deposition, diagenesis and preservation potential. The palynological record may contribute to distinguish different taphonomic factors and also displays changes in paleoenvironment, especially in volcanic settings where a very complex interaction of eruptive, gravitational and fluvial processes in time and space can be observed. Herein, we report on new palynological data from the Miocene Tepoztlán Formation. The 800 m thick formation mainly consists of pyroclastic rocks, mass flow units (lahars) and fluvial deposits. It is part of the southern Transmexican Volcanic Belt, cropping out south of the Valley of Mexico and within the two states of Morelos and Mexico State. The volcaniclastic succession records various stages of recovery of vegetation related to a wide variety of disturbance factors and mechanisms. During the entire period of deposition, mixed mesophytic forests appear to have been widespread in the lowlands along streams and midaltitude uplands surrounding the valley. Pollen assemblages were repeatedly reset by volcanic eruptions or their secondary effects (lahars) to more limited assemblages with gradual
\end{abstract}


recoveries to the initial stages before the eruption. A clear distinction can be made between samples taken from different transport regimes (fluvial, lahar and pyroclastic flow transport). The highest percentages of well-preserved, amorphous, and crumpled palynomorphs can be found in fluvial sediments while the highest percentage of fragmented palynomorphs is characteristic of lahar deposits. In contrast, the highest percentage of corroded palynomorphs can be found in deposits originating from pyroclastic flows.

\section{INTRODUCTION}

An understanding of taphonomic factors, such as the botanical origins, transport, and deposition of organic material and its preservation in fossil form, is vital in evaluating pollen records, particularly in the case of volcanic settings where a very complex interaction of eruptive, gravitational and fluvial processes can be observed. Palynomorphs are affected by various processes from the time of their distribution by wind, water or animals until recovery and analysis. Pollen production varies as a function of the vegetation (i.e. composition of the local plant community) as well as pollen production abilities and pollination mechanisms of plants in the community (Hofmann, 2002), but can reach well into the millions and possibly billions of grains per $\mathrm{m}^{2}$ in extreme cases (Campbell, 1999). Most pollen is destroyed or altered prior to, or soon after, incorporation into sediment. Therefore, the condition of preserved pollen can yield insight not only into differential preservation in a system but possibly also into the transport history of the pollen grains (c.f., Campbell, 1999). The ratio of fluvial to airborne (both wet and dry) transport and input depends on the relationship between the size of the catchment, the topography and the catchment vegetation (Brown et al., 2007). Dispersal of pollen and spores by wind is generally mostly restricted to very short distances (Streel and Bless, 1980). Rarely, aerial transport over long distances occurs, as known for instance from the Atlantic off West Africa (Melia, 1984). An exception are saccate and 
bisaccate pollen grains that can travel over hundreds of kilometers (Raynor et al., 1974; Stix, 1975; Gregory, 1978). Fluvial transport is most important for spore and pollen dispersal (Streel and Bless, 1980) and later burial in sediment, with transport distances up to several hundred kilometers known from recent river systems (Chmura et al., 1999). The fluvial pollen and spore load itself is a combination of several distinct components including: 1) an airborne component (directly into the channels from local to regional sources); 2) an overland flow component; 3) a bank erosion component; and 4) river storage in bed-sediments that can be resuspended during floods (Jacobson and Bradshaw, 1981; Brown et al., 2007). The same applies for debris flows and hyperconcentrated flows in volcanic environments (lahars) where palynomorphs are either introduced by wind, overland flow of water or erosion of loose volcaniclastic sediment. Therefore, during transport, a homogeneous mixture of pollen and spores is formed, representing available sources within the drainage basin (Groot, 1966). It is common in river settings for a significant fraction of a pollen assemblage to consist of redeposited pollen grains (e.g., Campbell and Chmura, 1994; Chmura et al., 1999). These can often readily be identified due to their different stratigraphic ranges (Stanley, 1966) and, in some cases, differences in preservation. In other cases, where the reworked pollen is not clearly older than the enclosing deposit, its presence may be more difficult to detect (Campbell, 1999). The duration of transport is controlled not only by the distance traveled but also by flow velocity and possible periods of temporary deposition and episodes of further transport (Jäger, 2004). Thus, pollen transport depends strongly on the depositional and transportational environment. However, actualistic studies from modern sedimentary environments suggest that most palynomorphs are parauchthonous (i.e. transported only over limited distances and buried within or near to the habitats in which the parent plants were growing; e.g., Scheihing and Pfefferkorn, 1984; Gastaldo et al., 1987, 1989a; DiMichele and Hook, 1992). Thus, although sedimentology-based taphonomical studies are necessary prior to any paleoecological interpretations (e.g., Gastaldo et al., 1989b; Calder et al., 1996), the 
fossil record of siliciclastic sediments can be used with some reliability to reconstruct former plant assemblages.

The geomorphology, variability of water/sediment discharge (Muller, 1959; Traverse, 1992), and geochemistry of the depositional site are all thought to be of important factors affecting the quality of preservation and diversity of preserved pollen grains and spores (Hofmann, 2002). Surprisingly, the transport process itself causes minimal pollen destruction (Campbell, 1991). However, subaerial exposure likely means an opportunity for oxidation, known to degrade pollen grains, and possibly further degradation by bacteria or fungi (e.g., Elsik, 1971). Additionally, the type of deposit into which the pollen is eventually incorporated also may affect the assemblage, as differential degradation may continue after deposition. Sediment accumulation rate is a particularly important environmental variable inferred to have an effect on the reactivity and ultimate preservation of organic matter (Hedges and Keil, 1995). This relationship might be expected because bacterial and animal activities are almost always highest near the sediment surface. Rapid deposition quickly moves organic matter through, and below this diagenetically active zone, possibly with overall less total degradation (Hedges and Keil, 1995). Pollen is perhaps oxidized more readily than it is damaged by most other means. Fire as well as incorporation into hot pyroclastic flows during volcanic eruptions is an extreme case of oxidation, which can destroy or damage pollen very rapidly when sufficient oxygen is available. Once incorporated into a deposit, pollen is subject to the same diagenetic processes that affect the rest of the sediment. Thermal alteration is principally observed as a progressive darkening of the grain, from yellow through orange-brown to redbrown, brown, and black (Graham, 1997). Thermal evolution continues until the point of lowgrade metamorphism without rendering the pollen grains fundamentally unrecognizable (Woods, 1955).

Studying the way in which a pollen assemblage has been preserved can help to determine whether a change within the pollen record reflects a genuine shift within the vegetational 
landscape, or is an artifact of some feature of the depositional or preservational environment (Tweddle and Edwards, 2010). Quantification of pollen occurrences and their preservation is an approach that can improve the confidence of interpretations of the vegetational environments by modern pollen studies (e.g., Bunting, 2003; Schofield et al., 2007) and theoretical models (e.g., Prentice, 1985; Jackson and Lyford, 1999; Sugita et al., 1999), particularly for sections of a record that display rapid palynological change, or that have been subject to fluctuating sedimentary conditions such as volcanic environments (c.f., Tweddle and Edwards, 2010).

In the present study, pollen preservation analysis is used as a tool to understand and interpret the palynological record of the volcaniclastic Miocene Tepoztlán Formation of Central Mexico. Throughout the Cenozoic period Central Mexico was widely affected by tectonic and volcanic activity. The Eocene and Oligocene in the study area experienced intensive folding and faulting (Fries, 1960). This tectonic instability led to changes in topography, allowing for the deposition of continental, clastic sediments within the newly formed basins. The Miocene to Quaternary interval was characterized by extensive volcanic activity. In the early to mid-Miocene a major volcano-tectonic change took place due to a reorganization of the western Pacific tectonic plates, and the Transmexican Volcanic Belt (TMVB) started to evolve (Delgado-Granados et al., 2000). The initial volcanic activity of the early TMVB is dated to ca. 22 Ma and is documented by the Tepoztlán Formation (Lenhardt et al., 2010, 2011, 2013; Lenhardt and Götz, 2011), cropping out in Malinalco (Mexico State) and in Tepoztlán and Tlayacapan (Morelos). The geology and geography of Morelos in Central Mexico controlled the evolution of the local flora and fauna (c.f., Lenhardt et al., 2006; Graham, 2010, 2011). However, little is known about initial activity of the TMVB and the impact of its evolution on the former environment and local climate. Cold temperate climates prevailed in upland areas of Central Mexico with forests dominated by Pinus and Picea (Lenhardt et al., 2008) during the Eocene and Oligocene (Martínez-Hernández and 
Ramírez-Arriaga, 1999) and likely during the Miocene as well (Lenhardt, 2009). The dry plains were characterized by subtropical species such as Caesalpinea, Mimosaceae, Bombacaceae, grasses and Ulmaceae, indicating savannah to scrubland vegetation, while slopes were covered by cloud forests consisting of species such as Engelhardia, Platanus and Ulmus (Martínez-Hernández and Ramírez-Arriaga, 1999).

\section{GEOLOGICAL AND ENVIRONMENTAL SETTING Regional Geological Setting}

The Transmexican Volcanic Belt (TMVB) is a continental magmatic arc formed by almost 8000 volcanic structures (Gómez-Tuena et al., 2007). It consists of a large number of Tertiary and Quaternary cinder cones, maars, domes, and stratovolcanoes with largely calc-alkaline mineralogical composition (Siebe and Macías, 2004). The TMVB developed as a result of the subduction of the Cocos and Rivera plates under the North American plate along the Middle American Trench, which was established during the Middle to Late Miocene (Ferrari et al., 2000). The TMVB is about $1000 \mathrm{~km}$ long and ranges from 80 to $230 \mathrm{~km}$ in width. In contrast with other subduction-related volcanic belts, running parallel to a deep-sea trench, the TMVB is oriented in an $\mathrm{E}-\mathrm{W}$ direction, forming an angle of about $16^{\circ}$ with the Middle America Trench (Gómez-Tuena et al., 2007).

The study area is located along the southern edge of the TMVB in the states of Morelos and Estado de Mexico (Fig. 1), where Lower Miocene volcaniclastic series (Tepoztlán Formation) are covered by Quaternary lavas and scoria of monogenetic volcanoes of the Chichinautzin volcanic field (Márquez et al., 1999; Siebe et al., 2004). 


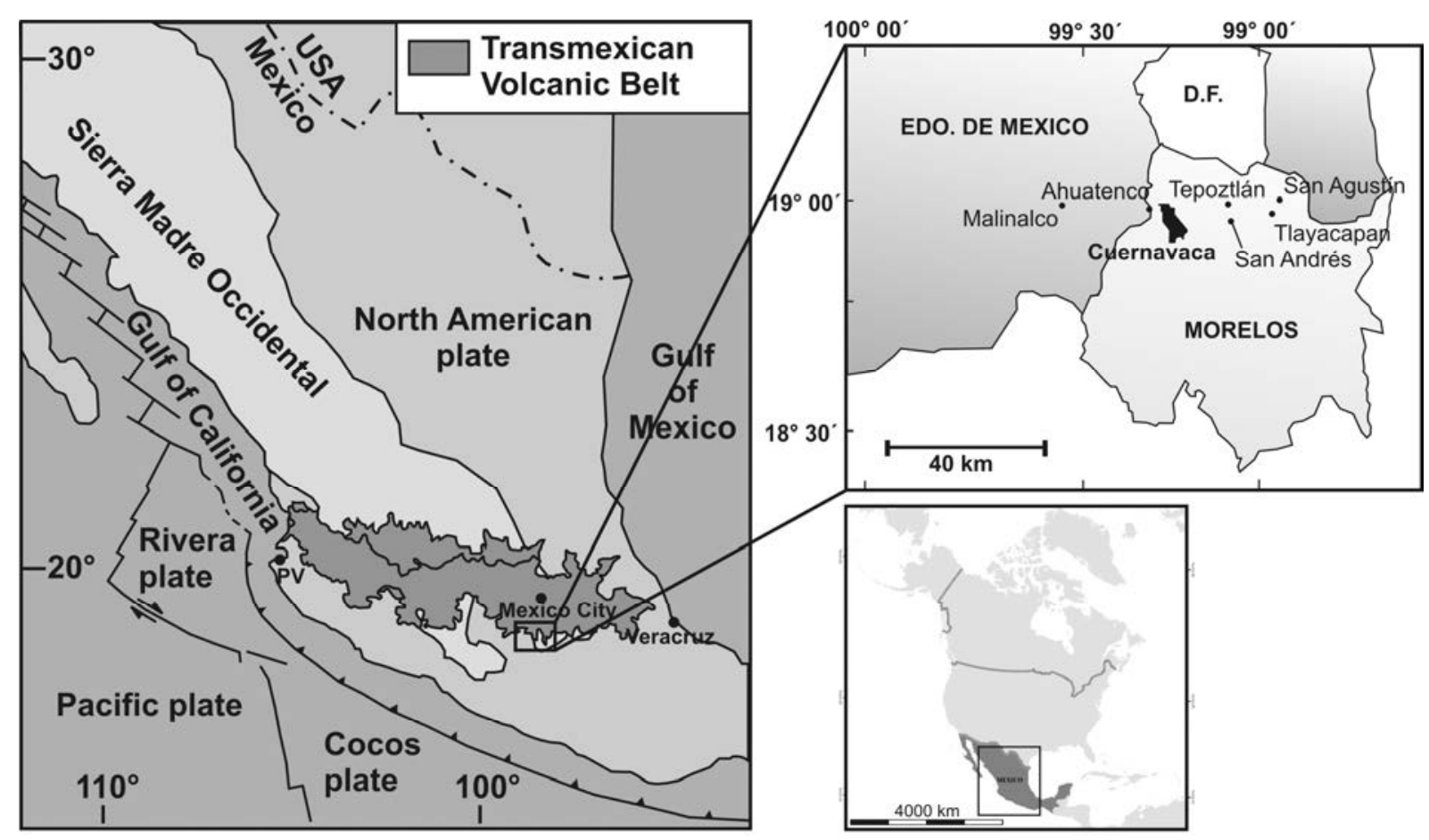

FIGURE 1 - Location map of the Transmexican Volcanic Belt in Central Mexico. Inset map at top right shows the locations around which the Tepoztlán Formation crops out (after Lenhardt et al., 2011).

The Tepoztlán Formation

The Tepoztlán Formation crops out in an area of approximately $1000 \mathrm{~km}^{2}\left(18^{\circ} 54^{\prime}-\right.$ $19^{\circ} 01^{\prime} \mathrm{N}$ lat, $98^{\circ} 57^{\prime}-99^{\circ} 32^{\prime} \mathrm{W}$ long) and has a maximum thickness of $800 \mathrm{~m}$. The formation is widespread around the villages of Malinalco and Chalma in Mexico State and Tepoztlán and Tlayacapan in Morelos. Small outcrops are also located east of Tlayacapan and southeast of Nevado de Toluca (Capra and Macías, 2000; García-Palomo et al., 2002).

The Tepoztlán Formation is composed of calc-alkaline volcanic and sedimentary rocks. The volcanic rocks have predominantly andesitic to dacitic compositions; however, rhyolite is also present. The entire succession comprises pyroclastic deposits (fall, surge and flow deposits), lahar deposits (debris-flow and hyperconcentrated-flow deposits) and coarse- to fine-grained fluvial and lacustrine deposits (conglomerate, sandstone and mudstone). The Tepoztlán Formation traditionally has been described as consisting of massive lahars rich in 
sub-rounded porphyritic andesite clasts intercalated with fluvial deposits (Fries, 1960; De Cserna and Fries, 1981). Bedding within the Tepoztlán Formation is generally flat-lying or gently dipping at up to $10^{\circ}$ to the N/ NNE. The lithological succession is disrupted by normal faults and dikes. Displacements adjacent to the faults of more than a few meters are rare, although displacements of about half a meter are common. Radiometric and paleomagnetic studies on lava and volcaniclastic sediments within the Tepoztlán Formation have yielded a depositional age of between 22.8 and 18.8 Ma (Fig. 2) (Lenhardt et al., 2010).
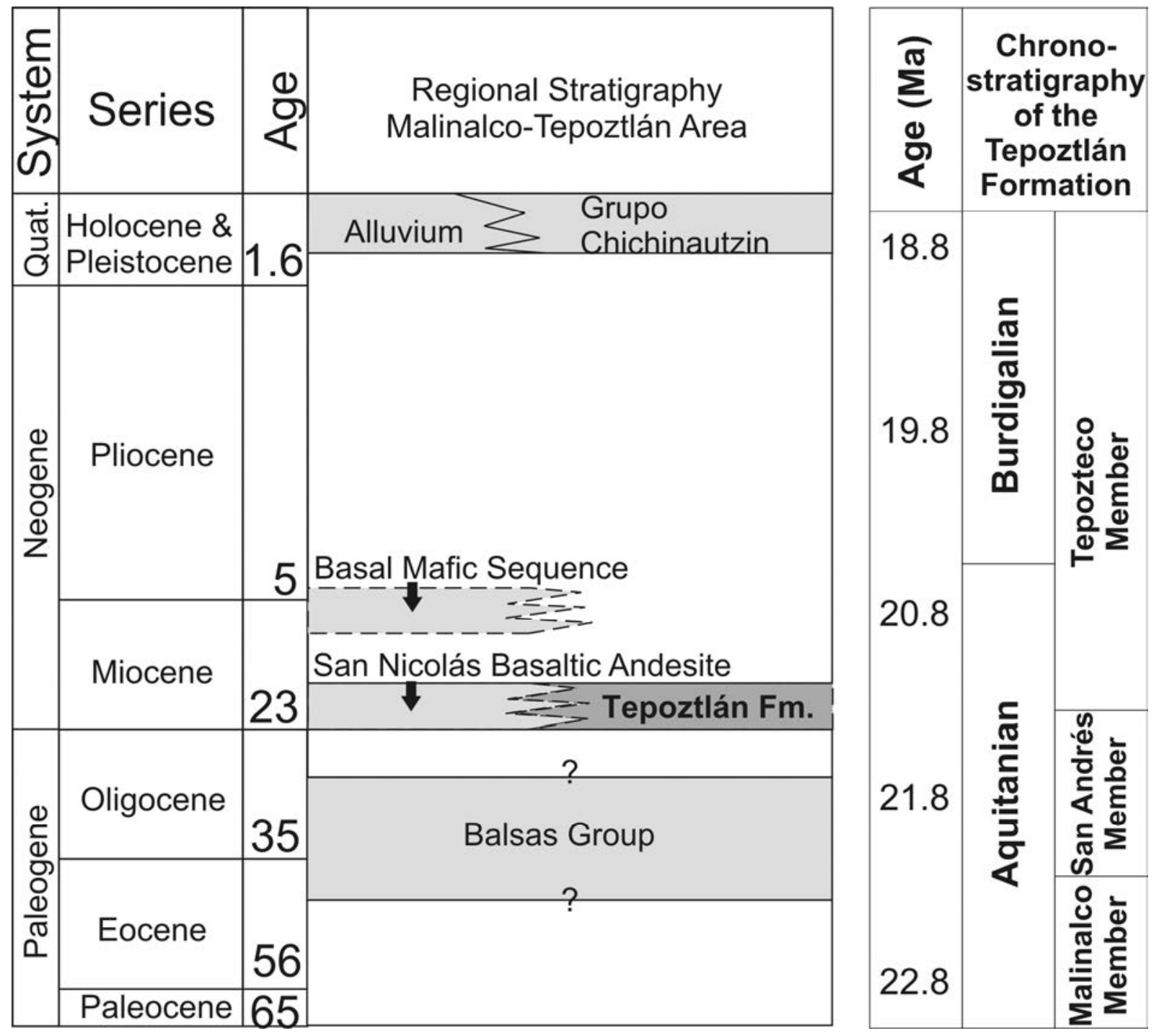

FIGURE 2 - Simplified stratigraphic column of Cenozoic strata in the study area interval (after Lenhardt et al., 2011). 


\section{Contemporary Setting}

The modern subtropical climatic conditions within the State of Morelos are characterized by hot, humid summers and dry winters under influence of the Mexican or North American monsoon (Adams and Comrie, 1997). The Mexican monsoon is experienced as a pronounced increase in rainfall from an extremely dry June to a rainy July. These summer rains typically last until mid-September when a drier regime is reestablished over the region (Douglas et al., 1993). The mean annual temperature is $20^{\circ} \mathrm{C}$, and the mean temperatures in August and in January are $24^{\circ} \mathrm{C}$ and $19.3^{\circ} \mathrm{C}$, respectively (Lenhardt, 2009). Precipitation is relatively low, $770 \mathrm{~mm}$ on average (Lenhardt, 2009). Most of the annual precipitation falls in summer (JuneSeptember).

Tepoztlán itself is located at an elevation of $1700 \mathrm{~m}$ above sea level. With an altitude of $2114 \mathrm{~m}$, Mt. Tepozteco (Cerro del Tepozteco) is the highest peak within the study area. To the north, the TMVB rises up to the Valley of Mexico at an elevation of $2240 \mathrm{~m}$. The southern end of the study area is characterized by wide plains and gentle hills of Cretaceous carbonates.

\section{Contemporary Vegetation}

The modern vegetation of the Tepoztlán area is characterized by grassland in the plains and the "tundra vulkanika" represented by lichens and shrubs (Fries, 1960) on top of the extensive lava fields in the north. In between, the slopes of the Tepoztlán Formation support mixed deciduous forests and coniferous forests (with Pinus montezumae as dominant species). The Miocene Tepoztlán flora is overall similar to that which currently characterizes Lake Zempoala (2800 $\mathrm{m}$ altitude, $\left.19^{\circ} 03^{\prime} \mathrm{N}, 99^{\circ} 81^{\prime} \mathrm{W}\right)$ where the forests are dominated by Quercus, Pinus and Abies (Miranda and Hernández-X, 1963). The lower montane forest belt (1800 2800 m) includes mesophyllous forest with Carpinus caroliniana, Garrya laurifolia, Tilia houghii and Acalypha phleoides (Luna et al., 1989). However, the same altitudinal interval on 
exposed mountain ridges and on drier slopes becomes a mixed forest $(2400-2800 \mathrm{~m})$ where Quercus laurina, Arbutus xalapensis and Pinus montezumae coexist with species of Salix and Viburnum. In the upper montane forest belt (2800-3700 m), two forest types, which occur in different altitude intervals, are recognized. From 2800 to 3550 m, Abies religiosa-dominated forest occurs, with Roldana angulifolia and Thuidium delicatulum in the understory (Miranda and Hernández-X, 1963). From 3550 to 3700 m, Pinus hartwegii-dominated forest with Festuca tolucensis and Festuca amplissima is common (Lauer, 1978).

\section{MATERIALS AND METHODS}

Sampling Localities

In an attempt to cover the entire sedimentary succession of the Tepoztlán Formation, samples were taken both north and south of the type locality (Tepoztlán, $18.59^{\circ} \mathrm{N}, 99.05^{\circ} \mathrm{W}$, $1717 \mathrm{~m}$ ) in two different stratigraphic sections, the San Andrés (SAN) and the Tepozteco (TEP) section (Figs. 3 and 4).

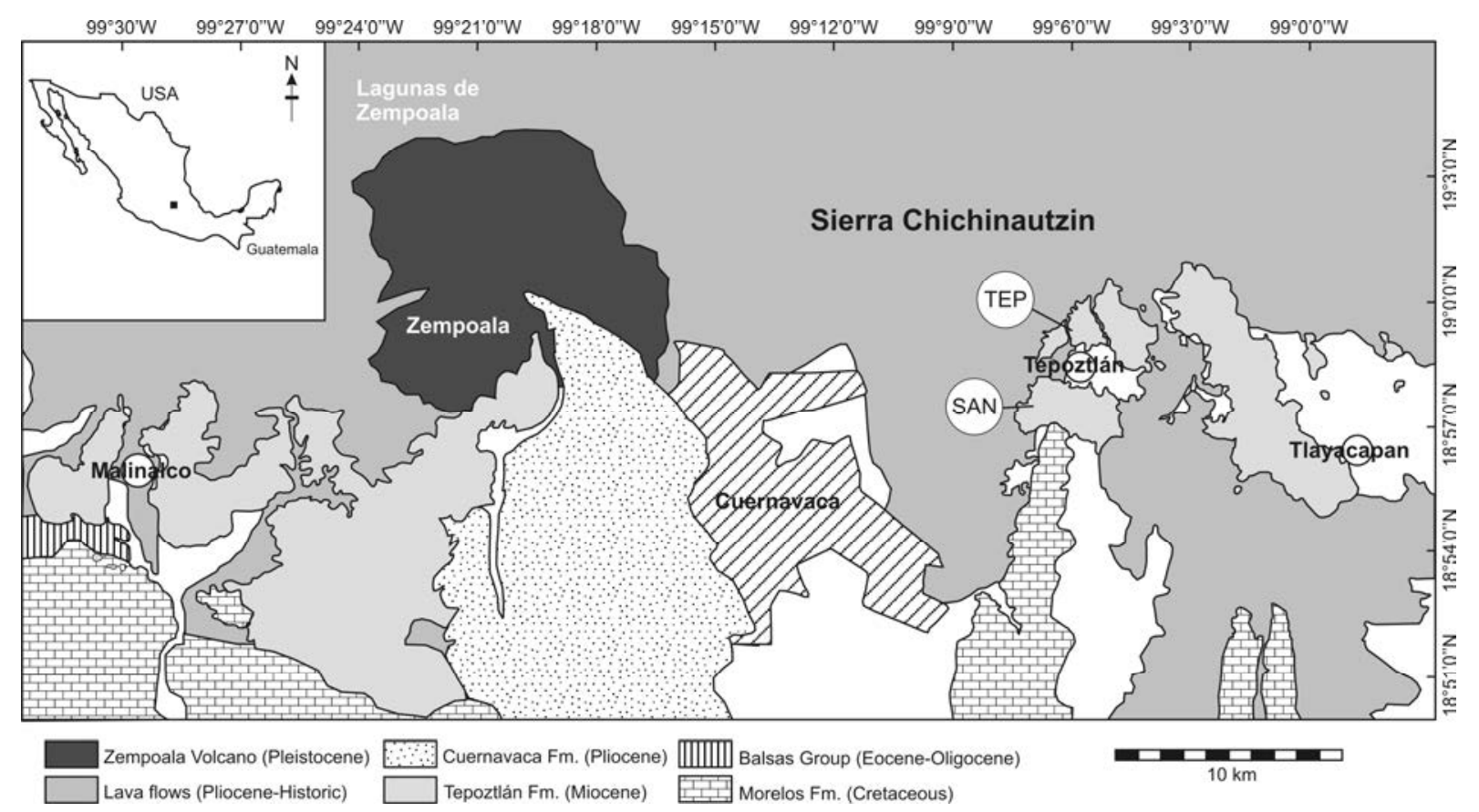

FIGURE 3 - Geological map of the study area showing the locations of the San Andrés

(SAN) and Tepozteco (TEP) sections (modified after Lenhardt et al., 2013). 
The San Andrés section (Fig. 4), with a thickness of 239 m, is located north of the village San Andrés $\left(18.95^{\circ} \mathrm{N}, 99.11^{\circ} \mathrm{W}\right)$. The lower part of the section is dominated by tuffaceous sandstone, conglomerate and breccia resulting from fluvial and mass flow processes. With increasing altitude, primary tuff beds become predominant features of the depositional system. At $180 \mathrm{~m}$ the section is dominated by primary tuffs and minor reworked units (e.g. fluvial and debris flow deposits) and is overlain by thicker strata of stacked ignimbrites with minor debris-flow deposits. The top of this section shows an increase in fluvial deposits again. The Tepozteco section (Fig. 4) is located north of the town of Tepoztlán $\left(18.99^{\circ} \mathrm{N}, 99.10^{\circ} \mathrm{W}\right)$. The thickness of this section is $378 \mathrm{~m}$. The lower part is dominated by tuffaceous sandstone and conglomerate representing gravel bars and sandy channel fill. Only minor amounts of primary volcanic material, derived from pumice-and-ash and block-and-ash flows, can be recognized. The upper two thirds of the section are dominated by coarse tuffaceous breccia (e.g. debris flow deposits resulting from lahars). Primary tuff beds are minor contributors to this part of the section. However, in the upper part a thick lava flow can be found. The top of the section is represented by more debris flow deposits with minor amounts of fluvial tuffaceous sandstone.

The sediments within the two stratigraphic sections accumulated in proximal to median environments (not more than $5-10 \mathrm{~km}$ from the source area), in flank and apron settings of a volcanic ring plain (shedding its debris from north to south), interfingering with an axial W-E trending braided river system (Lenhardt et al., 2010; 2011; 2013). While the lower part of the San Andrés section is still predominantly characterized by sandstones and conglomerates of the axial braided river system, the influence of the volcanic ring plain increases up-section and completely dominates the Tepozteco section (ca. $3 \mathrm{~km}$ towards the north). 


\section{Palynological Analyses}

For palynological analyses 38 samples (150 g each) representing various volcaniclastic lithologies were analyzed. Of these 23 samples turned out to be barren. The best results were attained from the fine-sandy layers of tuffaceous sandstone, very fine-grained layers on top of ignimbrite beds that were altered by soil forming processes, the fine-grained matrix of lahars and clayey to silty, thinly-bedded layers on top of lahars or fluvial deposits (waning flow deposits; Table 1). For the final analysis 15 samples from $1639 \mathrm{~m}$ to $2266 \mathrm{~m}$ were taken at irregular intervals depending on lithology (Fig. 4). All samples were processed following standard palynological processing techniques (Vidal, 1988), which include treatment with $\mathrm{HCl}(33 \%), \mathrm{HF}(73 \%)$ and heavy liquid separation with $\mathrm{ZnCl}_{2}$ solution. All samples were centrifuged and washed with distilled water after each step. The residue was cleaned by sieving using an $11 \mu \mathrm{m}$ mesh. For strew mounts we used Eukitt, a commercial mounting medium on the base of resin. All samples, residues and slides are archived in the Department of Geology at the University of Pretoria, South Africa.

The number of palynomorphs is low within the samples studied, which may be partially attributable to sediment type. Counts were based on a maximum of 200 pollen grains and spores per slide. Palynomorph preservation was classified according to Cushing (1967) (Table 2). The samples reveal a relatively well-preserved and diverse pollen and spore assemblage. Approximately 53 individual palynomorph taxa (pollen grains and spores, see Table 3) were identified and counted at 400x magnification. Percentages were calculated and plotted with Tilia Graph software (Grimm, 1992). 
TABLE 1 - Elevation, lithology (with mode of transport) and age of the samples taken for palynological analysis.

\begin{tabular}{|c|c|c|c|c|}
\hline $\begin{array}{l}\text { Stratigraphic } \\
\text { Section }\end{array}$ & $\begin{array}{l}\text { Elevation above } \\
\text { sea level }\end{array}$ & $\begin{array}{l}\text { Sample } \\
\text { No. }\end{array}$ & Lithology & Age \\
\hline \multirow{10}{*}{ Tepozteco } & $2266 \mathrm{~m}$ & 35 & $\begin{array}{l}\text { Tuffaceous breccia } \\
\text { (lahar) }\end{array}$ & $\begin{array}{l}19.0- \\
18.8 \mathrm{Ma}\end{array}$ \\
\hline & $2076 \mathrm{~m}$ & 32 & $\begin{array}{l}\text { Tuffaceous breccia } \\
\text { (lahar) }\end{array}$ & $\begin{array}{l}20.1- \\
19.0 \mathrm{Ma}\end{array}$ \\
\hline & $1906.7 \mathrm{~m}$ & 22 & $\begin{array}{l}\text { Tuffaceous sandstone } \\
\text { (fluvial) }\end{array}$ & \multirow{5}{*}{$\begin{array}{l}21.3- \\
20.9 \mathrm{Ma}\end{array}$} \\
\hline & $1904.7 \mathrm{~m}$ & 21 & $\begin{array}{l}\text { Tuffaceous sandstone } \\
\text { (fluvial) }\end{array}$ & \\
\hline & $1904.3 \mathrm{~m}$ & 20 & $\begin{array}{l}\text { Tuffaceous sandstone } \\
\text { (fluvial) }\end{array}$ & \\
\hline & $1904 \mathrm{~m}$ & 19 & $\begin{array}{l}\text { Tuffaceous sandstone } \\
\text { (fluvial) }\end{array}$ & \\
\hline & $1903.2 \mathrm{~m}$ & 18 & $\begin{array}{l}\text { Tuffaceous sandstone } \\
\text { (fluvial) }\end{array}$ & \\
\hline & $1881.5 \mathrm{~m}$ & 17 & $\begin{array}{l}\text { Tuffaceous sandstone } \\
\text { (fluvial) }\end{array}$ & $21.8-$ \\
\hline & $1881 \mathrm{~m}$ & 16 & $\begin{array}{l}\text { Tuffaceous sandstone } \\
\text { (fluvial) }\end{array}$ & $21.3 \mathrm{Ma}$ \\
\hline & $1848 \mathrm{~m}$ & 14 & $\begin{array}{l}\text { Tuffaceous breccia } \\
\text { (lahar) }\end{array}$ & $21.9-$ \\
\hline \multirow{5}{*}{ San Andrés } & $1843 \mathrm{~m}$ & 13 & Tuff (pyroclastic flow) & $21.8 \mathrm{Ma}$ \\
\hline & $1820.5 \mathrm{~m}$ & 8 & Tuff (pyroclastic flow) & $\begin{array}{l}22.2- \\
21.9 \mathrm{Ma}\end{array}$ \\
\hline & $1734.5 \mathrm{~m}$ & 6 & $\begin{array}{l}\text { Tuffaceous breccia } \\
\text { (lahar) }\end{array}$ & $\begin{array}{l}22.6- \\
22.5 \mathrm{Ma}\end{array}$ \\
\hline & $1639.7 \mathrm{~m}$ & 3 & $\begin{array}{l}\text { Tuffaceous sandstone } \\
\text { (fluvial) }\end{array}$ & \multirow{2}{*}{$\begin{array}{l}22.8- \\
22.6 \mathrm{Ma}\end{array}$} \\
\hline & $1639 \mathrm{~m}$ & 2 & $\begin{array}{l}\text { Tuffaceous sandstone } \\
\text { (fluvial) }\end{array}$ & \\
\hline
\end{tabular}



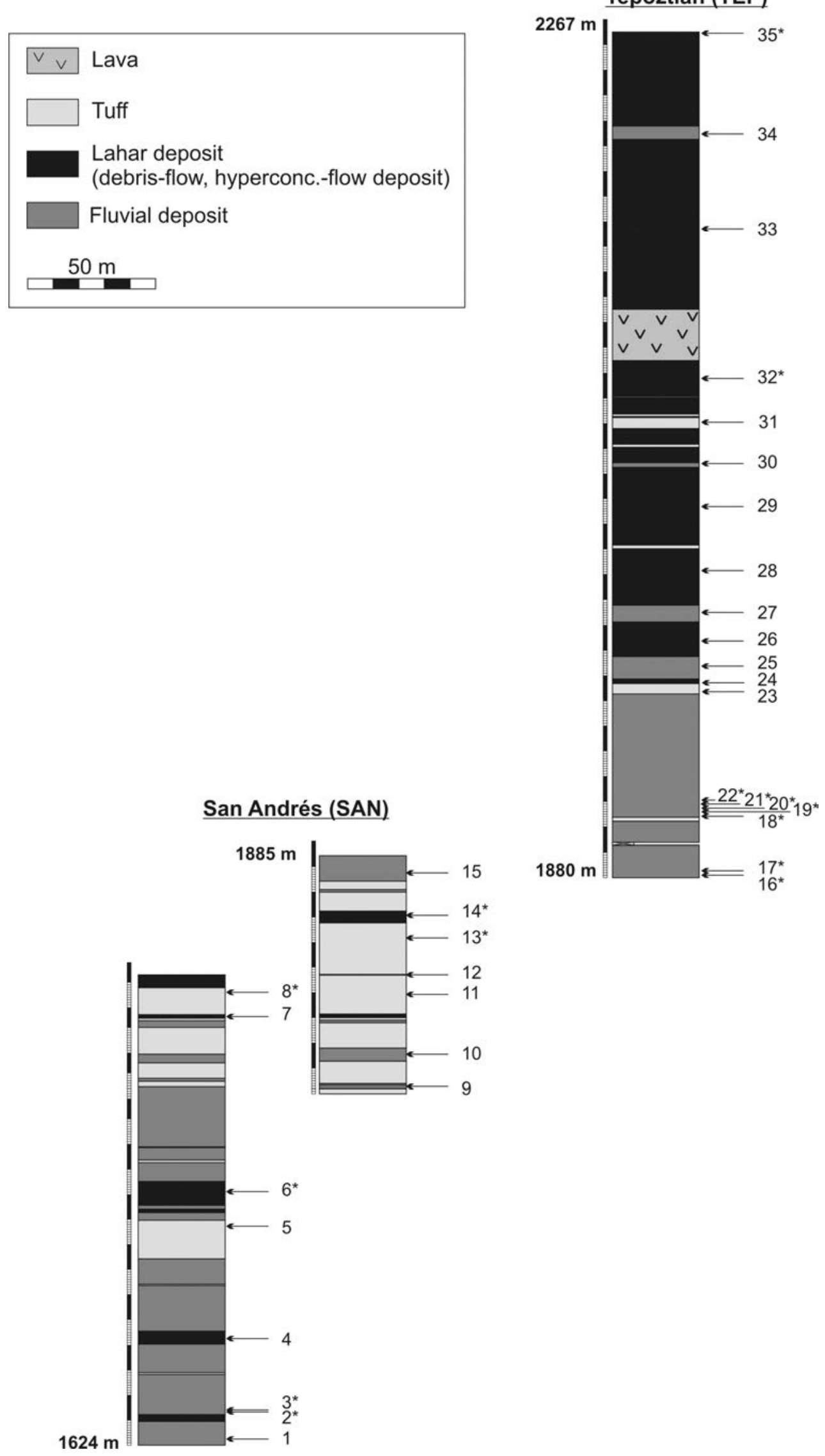
$4^{\star}$ 


\section{RESULTS}

Lithotypes and Palynomorph Preservation

Tuff. - Tuff layers (Fig. 5A) consist of a massive to finely laminated or cross-bedded, varicolored, poorly sorted mixture of medium to coarse volcanic ash, and were observed to be rich in lapilli in some cases. Thicknesses range from a few centimeters to several meters. Pyroclastic fall and pyroclastic density current deposits can be distinguished on the basis of texture and lithology. Pyroclastic fall deposits reach thicknesses of a few centimeters, drape topography and can be traced for several hundred meters throughout the outcrops. They consist of layers of well-sorted coarse ash particles, showing either normal or inverse grading. The particles are composed of pumice fragments and pyroxene crystals. The deposits of pyroclastic density currents can be further subdivided into units with stratification (ripples, cross-bedding, and antidunes), massive pumice-rich units and blocky tuff breccias rich in dense lava blocks.

In the present study only the fine-grained upper part of massive pumice-rich units, interpreted as ash-flow deposit and described by many authors as the most common ignimbrite lithofacies (e.g., Ross and Smith, 1961; Sparks, 1976; Wilson and Walker, 1982; Branney and Kokelaar, 2002; Lenhardt et al., 2011), were sampled. Tuffaceous breccias. - Within the sections studied there are a wide variety of reworked products associated with the primary volcaniclastic deposits. Among them, mass flow (or lahar) deposits (Fig. 5B) are characterized by tuffaceous breccia, originating from debris flows and hyper-concentrated flows, respectively (Lenhardt et al., 2011). Debris flow deposits are sheet-like, show no signs of grading or sorting and reach thicknesses up to $10 \mathrm{~m}$. The hyper-concentrated flow deposits, however, are up to $4 \mathrm{~m}$ thick, show erosional basal surfaces, normal or inverse grading and occasional diffuse sedimentary structures such as thin horizontal bedding and very low angle cross bedding. 
The tuffaceous breccias are composed of angular to subangular clasts in a pinkish red matrix of fine to medium-grained sand. The clast size is usually in the range of pebbles and cobbles, not exceeding diameters of $20 \mathrm{~cm}$. However, single outsized clasts of $2 \mathrm{~m}$ in diameter were observed. Clasts have similar characteristics and compositions as the primary deposits described above, and thus are interpreted to be reworked material from these deposits. The prevalence of angular to subangular volcanic clasts implies a local source, and thus suggests contemporaneous volcanism and sedimentation. The matrix is composed of approximately $30 \%$ lithic and pumice fragments (up to $1.2 \mathrm{~mm}$ ), $10 \%$ crystals and $60 \%$ glass shards (which show common alteration to clay). The pumice fragments were not observed to be aligned within the matrix. Palynology samples of the tuffaceous breccias were all taken from the fine-grained matrix between the clasts.

Tuffaceous sandstone. - Gray, cross-bedded, fine- to medium-grained sandstone (Fig. 5C) in the sections studied are interpreted as fluvial deposits. The sandstone occurs as sheets and lenses, characterizing channel fills, sand bar deposits, or fillings of scours, respectively (Lenhardt et al., 2011). The matrix consists primarily of sand-sized grains of lava, pumice or reworked ash particles. Based on the composition, the presence of crystals, pumice fragments and lava grains supports a pyroclastic origin of the sediment. However, the sedimentary structures indicate significant reworking of either primary or secondary pyroclastic deposits. Clast abrasion was minimal as shown by the subangular to subrounded shapes. The tuffaceous sandstone beds were deposited in a braided-river depositional setting (Lenhardt et al., 2011). Palynomorph preservation. - Within the Tepoztlán Formation five categories of preservation were recognized following Cushing's (1967) hierarchical classification:

(1) well-preserved, (2) corroded, (3) amorphous, (4) fragmented and (5) crumpled. Wellpreserved pollen grains show no obvious signs of damage, fragmented pollen grains have a distinctly ruptured exine in one or more places and crumpled pollen grains are twisted or folded along more than one axis (Cushing, 1967). Corroded pollen grains have exines 
displaying pitting or local etching (Havinga, 1984), or a more widespread thinning (Havinga, 1964; Holloway, 1989). Degraded pollen grains (amorphous sensu Lowe, 1982), are waxy in appearance with diffuse structural and sculptural elements that can only be resolved with difficulty.

The palynomorph classification of the Tepoztlán Formation is shown in Table 2. The highest percentage of well-preserved palynomorphs were found in fluvial deposits (tuffaceous sandstone) followed by lahar and pyroclastic flow deposits. Furthermore, fluvial deposits also show the highest amount of amorphous and crumpled palynomorphs among the analyzed lithologies. In contrast, tuffaceous breccias originating from lahars show the highest percentage of fragmented palynomorphs whereas the highest amounts of corroded palynomorphs were derived from tuff deposits.

TABLE 2 - Preservation of palynomorphs (percentages) in the main lithotypes of the Tepoztlán Formation. Inferred modes of transport of the sediments are given in brackets.

\begin{tabular}{|l|l|l|l|}
\hline $\begin{array}{l}\text { Preservation } \\
\text { of palynomorphs }\end{array}$ & $\begin{array}{l}\text { Tuff } \\
\text { (pyroclastic flow) }\end{array}$ & $\begin{array}{l}\text { Tuffaceous breccia } \\
\text { (lahar) }\end{array}$ & $\begin{array}{l}\text { Tuffaceous } \\
\text { sandstone (fluvial) }\end{array}$ \\
\hline well-preserved & 7.9 & 11.5 & 17.9 \\
\hline corroded & 30.2 & 25.7 & 17.3 \\
\hline amorphous & 36.5 & 33.6 & 40.3 \\
\hline fragmented & 12.7 & 15.0 & 9.7 \\
\hline crumpled & 12.7 & 14.2 & 14.8 \\
\hline
\end{tabular}



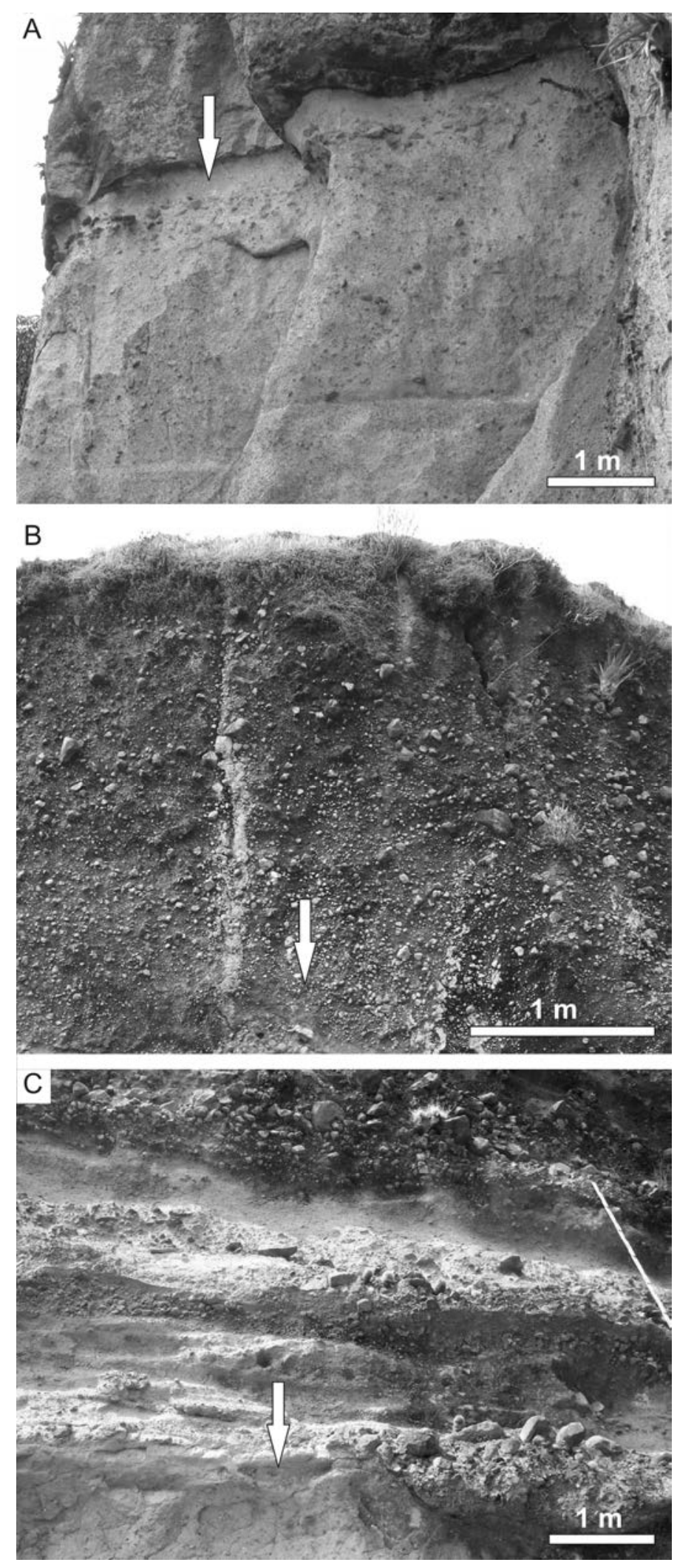

FIGURE 5 - Photographs showing examples of the three sampled lithofacies: a) tuff, b) tuffaceous breccia, c) tuffaceous sandstone. The white arrows mark representative sample horizons, including the fine-grained tops of tuff beds, the fine-grained matrix between the clasts in tuffaceous breccia, and fine- to medium-grained sandstone beds. 


\section{Palynological Assemblages}

The Tepoztlán palynoflora consists primarily of 38 angiosperm and 7 gymnosperm pollen taxa. In addition, 8 pteridophyte and bryophyte spore taxa occur in low abundances (see Table 3). The taxa can be assigned to riparian forest, deciduous forest and mixed coniferousbroadleaved forest plant communities. Cosmopolitan taxa occur in all of these plant communities. The only exception is Palmae, existing in subtropical to tropical arid areas.

Figures 6 and 7 document the palynomorphs of the San Andrés and Tepozteco sections and illustrate the changes in pollen and spore content within the Tepoztlán area. Pollen and spores are shown in percent of total pollen and spores. The diagrams are based on variations in the abundance of the dominant microflora taxa as well as the stratigraphical order in which samples were taken.

San Andrés section. - The San Andrés section (Fig. 6) represents 1.5 Ma of deposition (22.8 - 21.3 Ma). The base of the section is characterized by pollen grains of Pinus, Cupressaceae, Carya, Rutaceae, Cyperaceae, Poaceae, Betula, Alnus and Compositae sp. The relative abundance of Pinus is constant throughout the section, whereas Cupressaceae show an increase from sample 2 to sample 8 and a sudden decline to zero percent in sample 13, followed by a re-appearance in sample 14. Carya appears only once in the lower part of the section (sample 2) and then again at the top of the section in sample 14. Rutaceae show an increase from sample 2 to sample 3 and a decrease in sample 6. Upsection Rutaceae are absent. Cyperaceae increases up-section to sample 6. Above this, they decrease and are absent in overlying horizons (6-13) until they reappear in sample 14. Poaceae show a similar pattern throughout the section. Betula shows a general increase from the base to the top of the section, reaching its highest content in sample 13. Similar to the latter taxa is Alnus which exhibits an increase from sample 1 through sample 8, low abundance in sample 13 and high abundance in sample 14. In contrast, Compositae sp. shows an increase from sample 1 to sample 8, absence in sample 13 and reoccurs in sample 14. Tilia and Carpinus first appear in 
sample 6 and increase to sample 8. Tilia and Carpinus are absent in sample 13 and reoccur in sample 14. Quercus also has its first appearance in sample 6 but is characterized by a steady increase to sample 14. Finally, the first appearance of Artemisia and Fagus occurs in sample 14. The abundance of gymnosperms and angiosperms also varies throughout the section. Percentages of gymnosperm pollen taxa range between 10.9 to $20.7 \%$. Angiosperms range from 73.9 to $82.8 \%$. A steady increase in the abundance of tree pollen from sample 2 to sample 13 was observed while, in contrast, there is a steady decrease in the abundance of herb pollen within the same stratigraphic interval. This trend is reversed again from sample 14 upsection. The samples show a successive change of vegetation units, from riparian forest vegetation (samples 2-3) to deciduous forest elements (samples 6-8). Both elements dominate until sample 14.

Tepozteco section. - The Tepozteco section (Fig. 7) represents 3 Ma of deposition (21.8 18.8 Ma). The base of the section is characterized by the presence of Pinus, Cupressaceae, Poaceae, Tilia, Betula, Cyperaceae, Alnus, Carpinus, Compositae sp. and Artemisia. Pinus, identified in all samples, decreases in abundance from sample 16 at the base of the section to sample 20, followed by an increase to sample 35 . Cupressaceae steadily decrease from the base to sample 20 and are absent in samples from younger strata. Poaceae are present in all samples except sample 18, showing an increasing upwards trend. Similar to Poaceae, Tilia is present in all samples except sample 19. Betula is present in all samples except sample 17. After a reoccurrence in sample 18, Betula percentages are relatively steady and show a slight increase from sample 32 to sample 35. Cyperaceae occur in all samples besides sample 17. Castanea has its first appearance in sample 18, is absent in samples 19 to 34 and reappears within the highest sample in the section (sample 35). Alnus is present, albeit rare, at the base of the section and is absent in sample 17. After a re-appearance in sample 18 the amount of Alnus pollen grains is decreasing towards sample 35. Carpinus is characterized by more or less the same amount in all samples except for sample 17. Compositae sp. appears at the base 
of the section and is absent in samples 17 and 18, reoccurring in sample 19. From sample 19 to sample 20 Compositae sp. increase in abundance. Above this it decreases in abundance upsection. Quercus is absent in samples 17 and 18, reappears in sample 19, exhibits an upward increase until sample 32 and then decreases to the top of the section. Chenopodium sp. appears only in sample 20. Rutaceae also have their first appearance in sample 22 and show similar amounts throughout the upper part of the section. Artemisia occurs only in sample 32.

The sum and ratio of gymnosperms and angiosperms also show characteristic changes throughout the section. Percentages of gymnosperm pollen taxa range from 5.8 to $38.1 \%$ and angiosperms from 61.9 and $94.1 \%$. The two pollen types show opposite trends with a decrease from sample 17 to sample 20, followed by an increase to sample 35 in the case of gymnosperms. In contrast, angiosperms show an increase from sample 17 to 20 and a decrease upsection towards sample 35. A similar trend of opposing sine curves is recorded by the appearance of tree and herb taxa. Although samples 18 to 22 likely span less time since they are closely spaced, a successive trend in the pollen content is recognized within the Tepozteco section (Fig. 7). Samples 16 and 17 are characterized by a change from mixed deciduous and riparian to a solely deciduous forest, whereas in sample 18 deciduous and riparian elements re-appear together. This does not change in samples 18 to 35 although riparian elements clearly dominate in samples 21 and 22. 
TABLE 3 - List of pollen and spore taxa and their corresponding plant communities.

\begin{tabular}{|c|c|c|}
\hline Palynomorphs & Recent plant & $\begin{array}{l}\text { Plant community/ } \\
\text { vegetation unit }\end{array}$ \\
\hline & Pteridophyta / Bryophyta & \\
\hline Pteridophyta sp. & $\begin{array}{l}\text { Dennstaedtiaceae } \\
\quad \text { cf. Dennstaedtia sp. }\end{array}$ & Riparian/ deciduous forest \\
\hline Sporopollenites sp. 1 & Indet & - \\
\hline Sporopollenites sp. 2 & indet 2 & - \\
\hline Verrucingulatisporites sp. & Pteridaceae & Cosmopolitan \\
\hline Retitriletes sp. & $\begin{array}{l}\text { Lycopodiaceae } \\
\text { Lycopodium sp. }\end{array}$ & Deciduous forest \\
\hline cf. Stereisporites sp. & $\begin{array}{l}\text { Sphagnaceae } \\
\text { cf. Sphagnum sp. }\end{array}$ & $\begin{array}{l}\text { Wetland/ Riparian/ } \\
\text { deciduous forest }\end{array}$ \\
\hline Perinomonoletes sp. & $\begin{array}{l}\text { Polypodiaceae } \\
\text { cf. Blechnum sp. } \\
\text { cf. Asplenium sp. }\end{array}$ & Deciduous forest \\
\hline \multirow[t]{2}{*}{ Laevigatosporites $\mathrm{sp}$. } & Thelypteridaceae & Wetland/ Riparian forest \\
\hline & Gymnosperms & \\
\hline Inaperturopollenites sp.1 & Cupressaceae & Deciduous forest \\
\hline Pinuspollenites sp. 1-5 & $\begin{array}{l}\text { Pinaceae } \\
\text { Pinus sp. }\end{array}$ & $\begin{array}{l}\text { Coniferous/Mixed } \\
\text { coniferous-broadleaved } \\
\text { forest }\end{array}$ \\
\hline cf. Cedripites sp & $\begin{array}{l}\text { Pinaceae } \\
\text { Cedrus sp. }\end{array}$ & Deciduous forest \\
\hline Inaperturopollenites sp.2 & $\begin{array}{l}\text { Taxodiaceae } \\
\quad c f . \text { Sequoia sp. }\end{array}$ & Riparian forest \\
\hline cf. Piceapollis sp & $\begin{array}{l}\text { Pinaceae } \\
\quad \text { Picea } \mathrm{sp} .\end{array}$ & $\begin{array}{l}\text { Mixed coniferous- } \\
\text { broadleaved forest }\end{array}$ \\
\hline Abiespollenites sp. & $\begin{array}{l}\text { Pinacaceae } \\
\text { Abies sp. }\end{array}$ & $\begin{array}{l}\text { Coniferous/Mixed } \\
\text { coniferous-broadleaved } \\
\text { forest }\end{array}$ \\
\hline \multirow[t]{2}{*}{ Ephedripites sp. } & $\begin{array}{l}\text { Ephedraceae } \\
\text { Ephedra sp. }\end{array}$ & Cosmopolitan \\
\hline & Angiosperms & \\
\hline Cyperaceaepollis sp. & Cyperaceae & Riparian forest \\
\hline Graminidites sp. & Poaceae & Cosmopolitan \\
\hline Monocolpopollenites sp. & Liliaceae & Wetland/ riparian forest \\
\hline $\begin{array}{l}\text { Trivestibulopollenites } \\
\text { betuloides }\end{array}$ & $\begin{array}{l}\text { Betulaceae } \\
\text { Betula sp. }\end{array}$ & Riparian forest \\
\hline Momipites sp. & $\begin{array}{l}\text { Juglandaceae } \\
\quad \text { Engelhardia } \mathrm{sp} .\end{array}$ & Deciduous forest \\
\hline Triporopollenites sp. 1 & indet 1 & - \\
\hline Triporopollenites sp. 2 & $\begin{array}{l}\text { Apocyanaceae } \\
\text { cf. Prestoria sp. }\end{array}$ & Riparian forest \\
\hline Carpinidites sp. & $\begin{array}{l}\text { Betulaceae } \\
\text { Carpinus sp. (Carpinus cf. } \\
\text { tropicalis subsp. Mexicana) }\end{array}$ & Deciduous forest \\
\hline Periporopollenites sp. 1 & indet 2 & - \\
\hline
\end{tabular}




\begin{tabular}{|c|c|c|}
\hline Alnipollenites verus & $\begin{array}{r}\text { Betulaceae } \\
\text { Alnus sp. }\end{array}$ & Riparian forest \\
\hline Chenopodipollis sp. $1+2$ & $\begin{array}{l}\text { Amaranthaceae } \\
\text { cf. Iresine sp. } 1+2\end{array}$ & Cosmopolitan \\
\hline Periporopollenites sp. 2 & $\begin{array}{l}\text { Plantaginaceae } \\
\quad c f . \text { Plantago sp. }\end{array}$ & Cosmopolitan/ wetland \\
\hline Tricolpopollenites sp. 1 & cf. Brassicaceae & Cosmopolitan \\
\hline Quercoidites sp. 1 & $\begin{array}{l}\text { Fagaceae } \\
\quad \text { Quercus sp. } 1\end{array}$ & Deciduous forest \\
\hline Tricolpopollenites sp. 2 & indet 3 & - \\
\hline cf. Ilexpollenites sp. & $\begin{array}{l}\text { Aquifoliaceae } \\
\quad c f . \text { Ilex sp. }\end{array}$ & Deciduous forest \\
\hline Tricolpopollenites sp. 3 & indet 4 & - \\
\hline Tricolpopollenites sp. 4 & $\begin{array}{l}\text { cf. Brassicaceae, } \\
\text { cf. Oleaceae }\end{array}$ & Cosmopolitan \\
\hline Quercoidites sp. 2 & $\begin{array}{l}\text { Fagaceae } \\
\quad \text { Quercus sp. } 2\end{array}$ & Deciduous forest \\
\hline Quercoidites sp. 3 & $\begin{array}{l}\text { Fagaceae } \\
\text { Quercus sp. } 3\end{array}$ & Deciduous forest \\
\hline Tricolporopollenites sp. 1 & $\begin{array}{l}\text { Fagaceae } \\
\quad \text { Castanea sp. }\end{array}$ & Deciduous forest \\
\hline Tricolporopollenites sp. 2 & indet 5 & - \\
\hline Tricolporopollenites sp. $3+4$ & $\begin{array}{l}\text { Rutaceae } 1+2 \\
\text { Cf. Zanthaxylon sp. } 1+2\end{array}$ & Cosmopolitan \\
\hline Tricolporopollenites sp. 5 & indet 6 & - \\
\hline Compositoipollenites sp. 1 & Compositae 1 & Cosmopolitan \\
\hline Chenopodipollis sp. 3 & $\begin{array}{l}\text { Chenopodiaceae } \\
\text { Chenopodium } \mathrm{sp} .\end{array}$ & Cosmopolitan \\
\hline $\begin{array}{l}\text { Polyporopollenites } \\
\text { undulosus }\end{array}$ & $\begin{array}{l}\text { Ulmaceae } \\
\text { Ulmus cf. mexicana }\end{array}$ & Deciduous forest \\
\hline Tricolporopollenites sp. 5 & indet 7 & - \\
\hline Caryapollenites sp. & $\begin{array}{l}\text { Juglandaceae } \\
\text { Carya sp. }\end{array}$ & Riparian forest \\
\hline Tetracolporopollenites sp. 1 & indet 8 & - \\
\hline Tricolporopollenites sp. 6 & indet 9 & - \\
\hline Intratriporopollenites $\mathrm{sp}$ & $\begin{array}{l}\text { Tiliaceae } \\
\text { Tilia sp. (T. americana } \\
\text { var. mexicana) }\end{array}$ & Deciduous forest \\
\hline Artemisiapollenites sp. & $\begin{array}{l}\text { Compositae } \\
\quad \text { Artemisia sp. }\end{array}$ & Cosmopolitan \\
\hline Monocolpopollenites sp. 2 & Palmae & Subtropical/ tropical \\
\hline Periporopollenites sp. 3 & indet 10 & - \\
\hline Tricolporopollenites sp. 3 & indet 11 & - \\
\hline Tricolporopollenites sp. 6 & indet 12 & - \\
\hline Faguspollenites sp. & $\begin{array}{l}\text { Fagaceae } \\
\quad \text { Fagus sp. }\end{array}$ & Deciduous forest \\
\hline
\end{tabular}




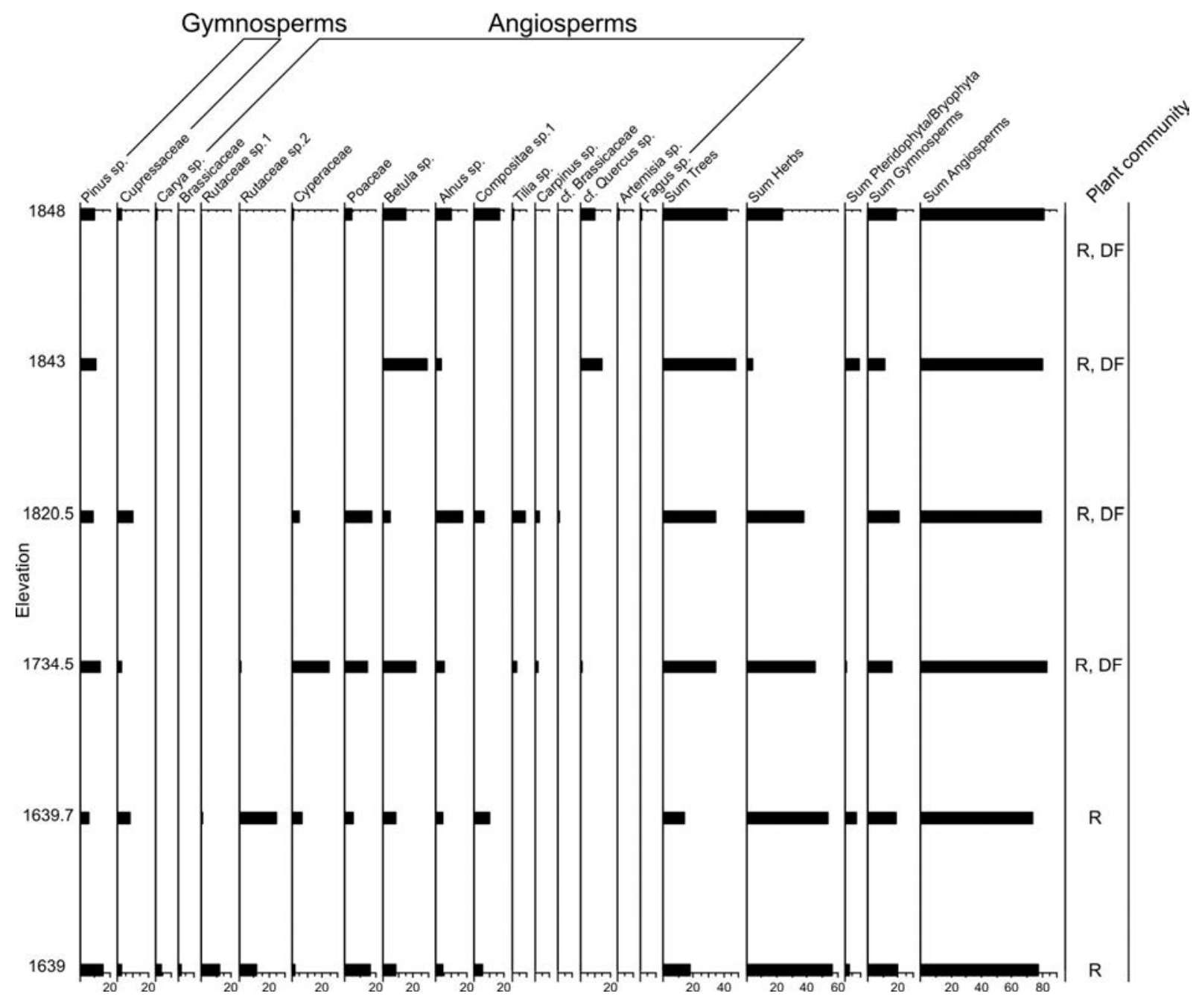

FIGURE 6 - Tilia diagram showing the palynomorph assemblage of the San Andrés section. $\mathrm{R}=$ riparian forest $\mathrm{DF}=$ deciduous forest. 


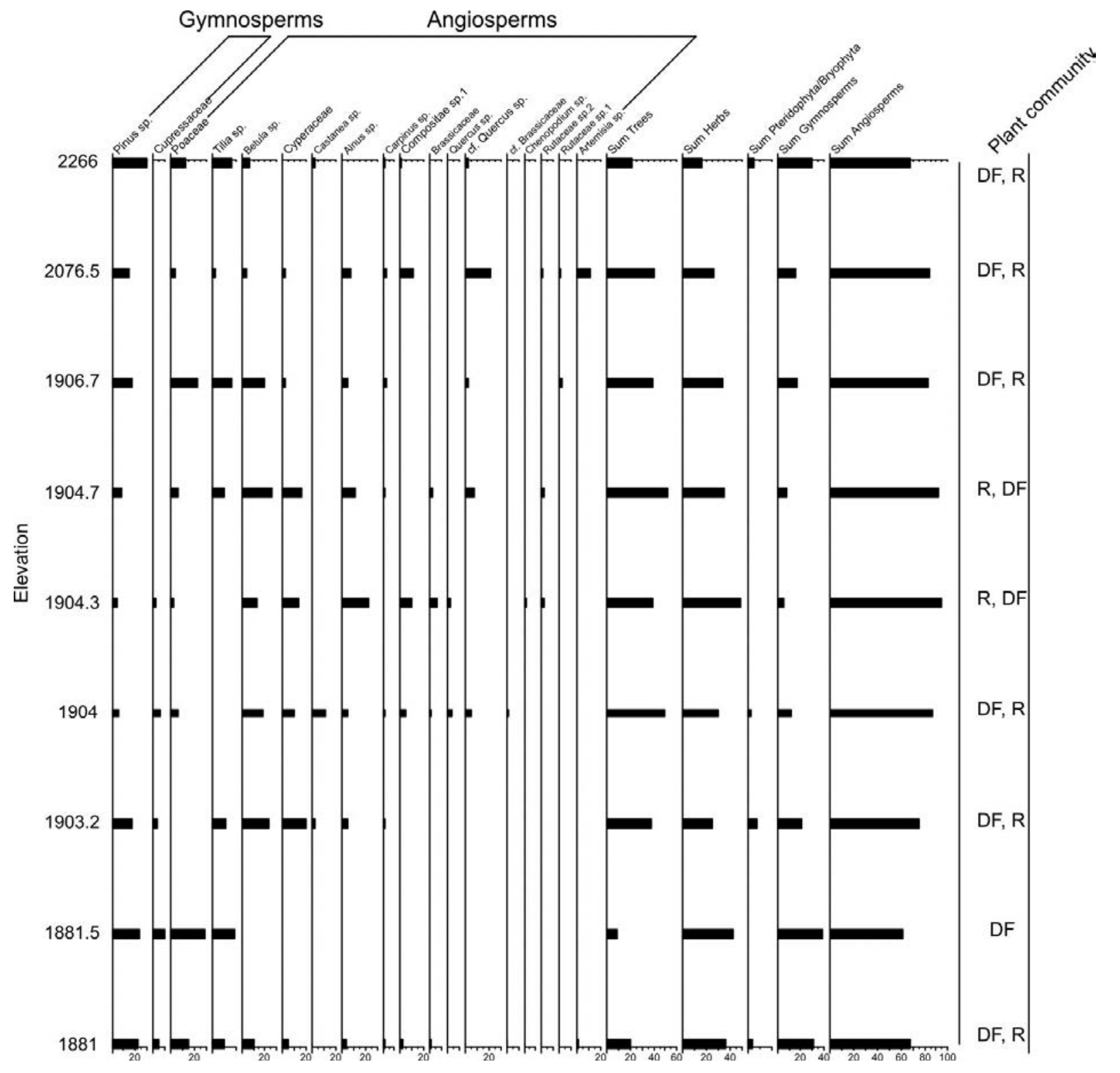

FIGURE 7 - Tilia diagram showing the palynomorph assemblage of the Tepozteco section. $\mathrm{R}=$ riparian forest $\mathrm{DF}=$ deciduous forest.

\section{DISCUSSION}

Taphonomic Implications

Palynomorphs can be considered as bioclasts with unusual sedimentological properties, and thus provide information about both the depositional setting and the upland source area (Campbell, 1999). It is therefore essential that the taphonomy of individual pollen grains is taken into account when interpreting palynological assemblages. Within the Tepoztlán 
Formation a clear distinction can be made between samples taken from different transport regimes (fluvial, lahar and pyroclastic flows), consistent with studies of other successions (e.g., Lowe, 1982; Tipping, 1995; Wilmhurst and McGlone, 2005) where a clear relationship between input of sediments and pollen deterioration has been recorded. As shown above, the highest percentage of well-preserved, amorphous, and crumpled palynomorphs occurs within fluvial sediments while the highest percentage of fragmented occurs within lahar deposits. In contrast, the highest percentage of corroded palynomorphs occurs within pyroclastic flow deposits.

Palynomorphs that are indeterminable, folded or fragmented were initially considered to have been damaged during transport as a result of sediment grinding. The expectation was that the more turbulent the transports and, concomitantly, the more clast or grain interactions that occurred, the higher the proportion of fragmented and crumpled pollen grains. This implies that pyroclastic deposits could be expected to contain a higher amount of fragmented and crumpled pollen grains than fluvial deposits because of their higher transport velocities and likely higher amount of grain to grain interactions. According to this model, the latter deposits should exhibit a higher amount of fragmented and crumpled pollen grains than lahar deposits with laminar flow. However, the opposite was observed within the Tepoztlán Formation (Table 2), with lahar deposits yielding $2.3 \%$ more fragmented and $1.5 \%$ more crumpled pollen grains than did pyroclastic flow deposits. Thus, other factors besides transport affect the preservation of palynomorphs and damage or destruction may probably not be related entirely to clast collision during transport, a hypothesis that was stated earlier by Campbell (1991) and Campbell and Chmura (1994). These authors suggested that preservation in all sedimentary facies types is similar, and that divergences must be related to other processes such as prolonged oxidation and repeated wet-dry cycles associated with multiple phases of deposition and reflotation (Lowe, 1982; Campbell and Campbell, 1994; Campbell, 1991). It has long been recognized that the state in which individual palynomorphs 
were preserved is highly variable, both within and between assemblages (e.g. Sangster and Dale, 1961, 1964; Cushing, 1967; Birks, 1970; Lowe, 1982). This is supported by palynomorph assemblages from the Tepoztlán Formation. It is herein observed that the corrosion of pollen grains is associated with oxygenated environments. The physical characteristics of corrosion may be caused by chemical oxidation (Brooks and Elsik, 1974), repeated wet and dry cycles (Holloway, 1989), and the actions of bacteria and fungi (Havinga, 1984). The susceptibility to corrosion differs from pollen type to type (Sangster and Dale, 1961, 1964), most likely as a result of species-specific variation in sporopollenin form and content (Brooks and Shaw, 1972). Nevertheless, chemical oxidation provides a good explanation for the fact that the highest percentage of corroded palynomorphs occurs within pyroclastic flow deposits, which are usually highly oxidizing environments due to high temperatures and chemical reactive gases.

The modes of origin of fragmented and crumpled pollen is less understood (Tweddle and Edwards, 2010), although high frequencies have been observed in association with fluvially deposited environments (Brown et al., 2007) and are thought to have resulted from multiple phases of transport and deposition prior to incorporation within a deposit. This hypothesis provides a good explanation for the high amounts of crumpled and fragmented palynomorphs in fluvial deposits and even higher amounts in lahar deposits of the Tepoztlán Formation. Sediment within lahar deposits may have multiple episodes of deposition and transportation.

Totally degraded palynomorphs are thought to occur as a result of both physical and chemical alteration of components of the pollen exine (Lowe, 1982).

Although the transport mechanism itself seems to have had minimal effect on the preservation of individual pollen grains, transport and deposition of palynomorphs, just like any other particle, is controlled by size, weight, shape and surface morphology (Jäger, 2004). Van der Zwan and van Veen (1978) observed that different lithologies show different size and sorting of palynomorphs. A clear influence of depositional environments on palynomorph 
assemblages was shown by Clayton (1985) to account for drastic local differences in quantity of age equivalent assemblages. Furthermore, Becker et al. (1974) suggested a direct relationship between the size range of a palynomorph assemblage and the grain size of the host sediment, leading to quantitative differences in assemblages due to grain size variations in different lithologies. Barren samples within the Tepoztlán Formation can be interpreted to be a function of the coarser grain-sizes of the sediment and the winnowing effect of flowing water within the river. This suggests that some of the features revealed in the pollen and spore diagrams may be artifacts of the dynamics of transport rather than simply reflecting changes in the surrounding vegetation. However, the fact that the sediment could not have been transported far distances away from the slopes of the volcanoes renders this effect negligible. On the other hand, Taggert and Cross (1990) suggested that the immense quantity of fine volcanic ash produced by proximal volcanic centers has a positive effect in facilitating fossil preservation. These sediments augment non-volcanogenic clastic sediment as poorly consolidated ash initially deposited on surrounding watersheds is eroded and transported. Thus, the potential for preservation of a fossil assemblage is higher in settings with active local volcanic centers compared with those in equivalent settings without volcanic input as a result of higher deposition rates and increased potential for rapid burial and thus protection of palynomorphs against the effects of stream erosion.

The color of pollen grains and spores within the Tepoztlán Formation generally ranges from light orange-brown to black, similar to the brown charcoal particles described by Umbanhowar Jr. and McGrath (1998). This is a sign that they were exposed to high temperatures. Charcoal created at $400^{\circ} \mathrm{C}$ and $350^{\circ} \mathrm{C}$ attains a dark black color whereas charcoal burned at $300^{\circ} \mathrm{C}$ is brown (Umbanhowar Jr. and McGrath, 1998). Thus, the particles in the study interval may have resulted from temperatures of approximately $300^{\circ} \mathrm{C}$ to $350^{\circ} \mathrm{C}$. 


\section{Paleoenvironmental Implications}

The volcaniclastic succession of the Tepoztlán Formation records various stages of recovery of vegetation related to a wide variety of disturbance factors and mechanisms. During the whole period of deposition of the Tepoztlán Formation, mixed mesophytic forests appear to have been widespread in the lowlands along streams and mid-altitude uplands surrounding the valley. Plant populations were frequently decimated by volcanic eruptions or their secondary effects (lahars). After each event, limited pollen assemblages were deposited, with gradual recoveries to the assemblages similar to pre-eruptive settings. This is consistent with similar floras and volcanic recovery stages described from lahar dammed (MacGinitie, 1953; Meyer, 2003) and caldera lakes (Wolfe and Schorn, 1989; Graham, 1963) from North America.

Palynomorph assemblages of most analyzed samples point to streamside assemblages bordered by moist volcanic highlands and patches of grassland. Forest elements can be divided into deciduous vegetation on hillslopes and riparian vegetation along rivers. Species of Pinus and Quercus dominated in the hillslope forests, accompanied by Alnus and Carpinus. Elements such as Alnus, Carya, Quercus, and Ulmus support the presence of cloud forests growing in wet ravines (Miranda, 1947; Rzedowski, 1978; 1996; Luna et al., 1988, 1994; Luna-Vega et al., 1989; Campos-Villanueva and Villaseñor, 1995; Alcántara and Luna, 1997; Mayorga et al., 1998). During the Paleogene (Late Eocene-Early Oligocene), the occurrence of cloud forest in southern Mexican basins is well documented by the Cuayuca and the Pie de Vaca Formations (Martínez-Hernández and Ramírez-Arriaga, 1999; Ramírez-Arriaga et al., 2008). This type of vegetation remained important until the Neogene. Examples include the Miocene of Pichucalco, Chiapas (Palacios and Rzedowski, 1993) and the Pliocene of Veracruz (Graham, 1975).

The inferred paleotopography in an evolving volcanic setting is consistent with the occurrence of mixed coniferous-hardwood forests in elevated areas. This is supported by the 
presence of Picea and Abies. The presence of Picea is particularly interesting since it no longer occurs in central or southern Mexico (Graham, 1989). In modern Latin America, Carpinus and Ilex can be found at elevations above $1500 \mathrm{~m}$ (Marchant et al., 2002). In association with Pinus and Quercus they formed the Miocene analogue of a Quercus-Pine dominated forest, growing at elevations between 1500 and $2800 \mathrm{~m}$ in present-day Mexico (Graham, 1989). Pinus dominated forests are also well documented from the Late EoceneEarly Oligocene Pie de Vaca Formation in Puebla (Martínez-Hernández and Ramírez-Arriaga, 1999).

Swamps or riparian forests growing along rivers were dominated by Cyperaceae, Cupressaceae/Taxodiaceae and Carya. The herbaceous plants are mainly composed of Poaceae, Compositae and Chenopodiaceae. The maximum distribution of herbaceous vegetation is recorded in the lower part of the San Andrés section with higher proportions of its components. This vegetation can either be attributed to patches of open grass- and shrubland or the lower levels of open forest vegetation. The general increase of species associated with a Pinus-Quercus forest shows an increasing influence of hillslope vegetation on the pollen record. A general decrease in riparian vegetation also occurs within the two stratigraphic sections.

All sediments of the sections studied are locally derived and were deposited in proximal to median distances from the source area. With few exceptions, all pollen taxa group in one of the vegetation units described in Table 3 , suggesting that they were locally derived. Exceptions include tropical taxa such as Palmae and Engelhardia, which were excluded from the analyses. These taxa were most likely derived from lower altitudes that were influenced by tropical climates and vegetation. Graham (1988) described Palmae (Cryosophia and Manicaria type) and Engelhardia in the Lower Miocene Cucaracha Formation of Panama and suggested that their ecology consisted of fern marsh with associated palms community of mangrove (Rhizophora) and tropical wet and premontane forests. Palacios and Rzedowski 
(1993) describe the occurrence of a Lower Miocene cloud forest with Engelhardia in Chiapas. Closer to the study area, but of Middle Pliocene age, the Paraje Solo Formation (MachainCastillo, 1985) near Veracruz provides a record of vegetation extending from coastal mangrove swamps, to upland Quercus-Liquidambar and Quercus-Pinus forests, to highland communities of Abies-Pinus in the eastern Transmexican Volcanic Belt.

The vegetational units identified in the Tepoztlán Formation appear independent of the sedimentology, as indicated by continuity of riparian and deciduous forest vegetation throughout all lithologies. Within the San Andrés section samples 2 to 8 represent fluvial, mass flow and pyroclastic sediments. While there is riparian forest vegetation in samples 2 to 3 exclusively, samples 6 to 8 show additional elements of a deciduous forest, indicating that the vegetation, which was formerly concentrated near the stream at the riverbanks, spread out of the valley and began to populate the planes and hillslopes where a deciduous forest formed. Due to the deposition of the sediments by mass flow and pyroclastic flow processes, the appearance of taxa growing outside the river valley could alternatively be interpreted as the result of sediment transport from higher regions on the volcanic slopes. However, no significant increase in the number of palynomorphs or in taxa, and no taxa specific to high elevations, could be documented. This is contrary to expectations if the sediment had in fact been transported from high elevations. The influence of higher-elevation taxa on the pollen assemblage due to mass flow transport processes on the flanks of the volcano is thus considered to be minor.

Sample 13 represents the fine-grained top of an ash-flow deposit. This sample illustrates the effect of a volcanic eruption on vegetation. The variety of taxa within this zone is very restricted and limited to ferns, Alnus, Betula, Quercus and Pinus. Ferns are among the typical early colonizers of volcanic sites and are documented in the aftermath of many eruptions (Richards, 1996; Harrison et al., 2001). Alnus has the capability of fixing nitrogen and can even grow on pure sand. Similar to Betula it is found in disturbed riparian sites in Alaska 
(Shelford, 1963) and on volcanic ash in Japan (Tagawa, 1964). The destruction of forest elements in the valley due to volcanic eruptions and the deposition of pyroclastic sediments within the valley resulted in a reduction of these pollen, while forest elements on adjacent slopes were largely unaffected, resulting in a peak of oak pollen. A similar occurrence was described by Taggart and Cross (1982) from Oregon. The limited variety of pollen within this zone raises the question why there is a lack of herbaceous taxa, which should appear right after the primary colonization by ferns. Taggart and Cross $(1974,1980,1982)$ carried out studies on the consequences of direct volcanic disturbance at Succor Creek, Oregon/Idaho. Samples taken from above the volcanic disturbance events were observed to be dominated by herbaceous dicots (Composite, Malacca, Chenopodiaceous, and Amaranthaceous) and grasses, typically followed by pine parkland which could explain the Pinus pollen found within the Tepoztlán samples.

Sample 14 represents a debris-flow deposit resulting from a lahar that was initiated after the eruption. During this period, the vegetation was already recovering and had increased in variety, following the general trend to a dominating dry, deciduous forest with riparian elements. This corresponds to studies carried out in Papua New Guinea (Lentfer and Torrance, 2007). Each successional process was interrupted by the next eruptive episode after which the vegetation followed a general trend. In areas with less volcanic impact, regeneration started at a more advanced level. In general, the pollen diagram of the San Andrés section shows that the deciduous forest vegetation became denser in the course of the succession. On the other hand, the environment became drier as documented in the decrease of taxa such as Cyperaceae. Nevertheless, the dominating vegetation type remained a riparian forest vegetation.

Within the Tepozteco section, samples 16 to 22 represent fluvial sediments while samples 32 to 35 represent primarily debris-flow deposits, thus, being a direct indicator for explosive eruptions in the near past and vicinity. Due to closer sampling intervals at the base and more 
widely spaced sample intervals at the top, trends are not as obvious within this section.

Nevertheless, a continuity of deciduous forest vegetation together with riparian elements is documented. The San Andrés and Tepozteco sections both show significant similarities in their vegetational development, especially in the area of temporal overlap at the top of the San Andrés section and the base of the Tepozteco section.

\section{CONCLUSIONS}

The results of the Miocene Tepoztlán study show that a clear distinction can be made between samples taken from different transport regimes (fluvial, lahar and pyroclastic flow transport). The highest percentages of well-preserved, amorphous, and crumpled palynomorphs occur in fluvial sediments while the highest percentage of fragmented palynomorphs is characteristic of lahar deposits. In contrast, the highest percentage of corroded palynomorphs occurs in deposits originating from pyroclastic flows. These findings confirm earlier hypotheses that the transport mechanism itself may not represent the major effect on the preservation of palynomorphs and divergences must be related to other processes typical for a certain type of deposit, such as prolonged oxidation and repeated wet-dry cycles associated with multiple phases of deposition and reflotation.

Furthermore, the palynomorph assemblages of the Tepoztlán Formation imply that the volcaniclastic succession records various stages of recovery of vegetation related to a wide variety of disturbance factors and mechanisms. During the entire period of deposition of the formation, mixed mesophytic forests appear to have been widespread in the lowlands along streams and mid-altitude uplands surrounding the valley. Pollen assemblages indicate that plants in the Tepoztlán system were repeatedly reset by volcanic eruptions or their secondary effects (lahars) to more limited assemblages with gradual recoveries to the initial stages before the eruption. 


\section{ACKNOWLEDGEMENTS}

Palynological studies on the Miocene Tepoztlán Formation were carried out in the framework of a Doctoral thesis by the first author, funded by the Deutsche Forschungsgemeinschaft (DFG); project HI 643/5-1. The University of Pretoria Research Development Program (RDP) is acknowledged for financial support. Senckenberg Research Institute and Natural History Museum, Frankfurt kindly supported the analysis of pollen assemblages. Two anonymous reviewers and editors John-Paul Zonneveld and Jill Hardesty are thanked for their constructive remarks.

\section{REFERENCES}

AdAMs, D.K., and ComRIE, A.C., 1997, The North American Monsoon: Bulletin of the American Meteorological Society, v. 78(10), p. 2197-2213.

AlCÁNTARA, A.O., and LuNA, V.I., 1997, Florística y análisis biogeográfico del bosque mesófilo de montaña de Tenango de Doria, Hidalgo, México: Annales del Instituto de Biología, Universidad Nacional Autónoma de México, Serie Botánica, v. 68(2), p. 57-106.

BeCKer, G., Bless, M.J.M., Streel, M., and ThOReZ, J., 1974, Palynology and ostracode distribution in the basal Dinantian of Belgium and their dependence on sedimentary facies: Mededelingen van de Rijks Geologische Dienst, v. 25(2), p. 1-99.

BIRKS, H.J.B., 1970, Inwashed pollen spectra at Loch Fada, Isle of Skye: New Phytologist, v. 69, p. $807-820$. 
Branney, M.J., and KoKelaAr, P., 2002, Pyroclastic density currents and the sedimentation of ignimbrites: Memoir Geological Society London, v. 27, 143 pp.

Brooks, J., and ElsiK, W.C., 1974, Chemical oxidation (using ozone) of the spore wall of Lycopodium clavatum: Grana, v. 14, p. 85-91.

Brooks, J., and SHAw, G., 1972, Geochemistry of sporopollenin: Chemical Geology, v. 10, p. 69-87.

Brown, A.G., CARPenter, R.G., and WALling, D.E., 2007, Monitoring fluvial pollen transport, its relationship to catchment vegetation and implications for palaeoenvironmental studies: Rev. Palaeobot. Palynol., v. 147, p. 60-76.

Bunting, M.J., 2003. Pollen-vegetation relationships in non-arboreal moorland taxa: Review of Palaeobotany and Palynology, v. 125, p. 285-298.

Calder, J.H., Gibling, M.R., Eble, C.F., ScotT, A.C., and MacNeil, D.J., 1996, The Westphalian D fossil lepidodendrid forest at Table Head, Sydney Basin, Nova Scotia: sedimentology, paleoecology, and floral response to changing edaphic conditions: International Journal of Coal Geology, v. 31, p. 277-313.

CAMPBELL, I.D., 1991, Experimental mechanical destruction of pollen grains: Palynology, v. 15, p. 29-33. 
CAMPBELl, I.D., 1999, Quaternary pollen taphonomy: examples of differential redeposition and differential preservation: Palaeogeography, Palaeoclimatology, Palaeoecology, v. 149, p. $245-256$.

CAmpbell, I.D., and CAMPBell, C., 1994, Pollen preservation: experimental wet-dry cycles in saline and desalinated sediments. Palynology, v. 18, p. 5-10.

CAmpbell, I.D., and Chmura, G.L., 1994, Pollen distribution in the Atchafalya River, U.S.A: Palynology, v. 18, p. 55-65.

CAmpos-VillanueVa, A., and ViLlaSEÑOR, J.L., 1995, Estudio florístico de la porción central del municipio de San Jerónimo Coatlán, Distrito de Miahuatlán (Oaxaca): Boletín de la Sociedad Botánica de México, v. 56, p. 95-120.

CAPRA, L., and MACÍAS, J.L., 2000, Pleistocene cohesive debris flows at Nevado de Toluca Volcano, central Mexico: Journal of Volcanology and Geothermal Research, v. 102, p. 149167.

Chmura, G.L., Smirnov, A., and CAmPBell, I.D., 1999, Pollen transport through distributaries and depositional patterns in coastal waters: Palaeogeography, Palaeoclimatology, Palaeoecology, v. 149, p. 257-270.

Clayton, G., 1985, Dinantian miospores and inter-continental correlation: C. R. 10ème Congrès de Stratigraphie et Géologie du Carbonifère, v. 4, p. 9-23. 
CusHING, E.J., 1967, Evidence for differential pollen preservation in Late Quaternary sediments in Minnesota: Review of Palaeobotany and Palynology, v. 4, p. 87-101.

De Cserna, Z., and FrIES, C., 1981, Hoja Taxco 14 Q-h (7), con resumen de la geología de la hoja Taxco, estados de Guerrero, México y Morelos: Universidad Autónoma de México, Instituto de Geología, Carta Geológica de México, Serie 1:100 000, map with text, 47 p.

Delgado-Granados, H., AguiRre-DíAZ, G.J., and Stock, J.M., 2000, Cenozoic tectonics and volcanism of Mexico - Preface: GSA Special Paper, v. 334, 275 p.

DiMichele, W.A., and HooK, R.W., 1992, Paleozoic terrestrial ecosystems. in Behrensmeyer, A., Damuth, J., DiMichele, W.A., Potts, R., Sues, H.-D., and Wing, S., eds., Terrestrial Ecosystems Through Time: University of Chicago Press, Chicago, p. 205326.

Douglas, M.W., Maddox, R., Howard, K., and ReYes, S., 1993, The Mexican Monsoon: Journal of Climate, v. 6, p. 1665-1667.

ELSIK, W.C., 1971. Microbial degradation of sporopollenin. in BROOKS, J., GRANT, P.R., Muir, M., VAN GiJZEL, P., and SHAw, G., eds., Sporopollenin: Academic Press, New York, NY, p. 480-511.

Ferrari, L., Vaggelli, G., Petrone, C., Manetti, P. and Conticelli, S., 2000, Late Miocene volcanism and intra-arc tectonics during the early development of the TransMexican Volcanic Belt. Tectonophysics, v. 318, p. 161-185. 
FRIES, C., 1960, Geología del Estado de Morelos y de partes adyacentes de México y

Guerrero, región central meridional de México: Boletín del Instituto Geología, UNAM, v. 60, p. 1-236.

García-Palomo, A., Macías, J.L., Arce, J.L., CAPra, L., Garduño, V.H., and EsPíndola, J.M., 2002, Geology of Nevado de Toluca volcano and sorrounding areas, central Mexico: Geological Society of America Map and Chart Series MCH089, 48 p.

GaStaldo, R.A., Douglass, D.P., and MCCARroll, S.M., 1987, Origin, characteristics and provenance of plant macrodetritus in a Holocene crevasse splay, Mobile delta, Alabama: Palaios, v. 2, p. 229-240.

Gastaldo, R.A., Bearce, S.C., Degges, C., Hunt, R.J., Peebles, M.W., and Violette, D.L., 1989a, Biostratinomy of a Holocene oxbow lake: a backswamp to mid-channel transect: Review of Palaeobotany and Palynology, v. 58(1), p. 47-60.

Gastaldo, R.A., GiBson, M.A., and GRAY, T.D., 1989b, An Appalachian-sourced deltaic sequence, northeastern Alabama: biofacies-lithofacies relationships and interpreted community patterns: International Journal of Coal Geology, v. 12, p. 225-257.

Gómez-Tuena, A., Orozco-Esquivel, MA.T., and Ferrari, L., 2007, Igneous petrogenesis of the Trans-Mexican Volcanic Belt. in AlANIZ-ÁlvareZ, S.A., and NIETO-SAMANIEGO, Á.F., eds., Geology of México: Celebrating the Centenary of the Geological Society of México: GSA Special Paper, v. 422, p. 129-181. 
GRAHAM, A., 1963, Systematic Revision of the Sucker Creek and Trout Creek Miocene Floras of Southeastern Oregon: American Journal of Botany, v. 50(9), p. 921-936.

GRAHAM, A., 1975, Late Cenozoic evolution of tropical lowland vegetation in Veracruz, México: Evolution, v. 29, p. 723-735.

GraHAM, A., 1988, Studies in Neotropical Paleobotany V. The Lower Miocene communities of Panama - the La Culebra Formation: Annals of the Missouri Botanical Garden, v. 75, p. $1440-1466$.

GrahAM, A., 1989, Studies in Neotropical Paleobotany VII. The Lower Miocene communities of Panama - the La Boca Formation: Annals of the Missouri Botanical Garden, v. 76 , p. $50-66$.

GRAHAM, A., 1997, Forensic palynology and the Ruidoso, New Mexico plane crash: Journal of Forensic Sciences, v. 42, p. 391-397.

GraHAM, A., 2010, Late Cretaceous and Cenozoic History of Latin American Vegetation and Terrestrial Environments: Missouri Botanical Garden Press, St. Louis, 617 p.

GraHAM, A., 2011, A Natural History of the New World: University of Chicago Press, Chicago, 408 p.

GREGORY, P.H., 1978, Distribution of airborne pollen and spores and their long distance transport: Pure and Applied Geophysics, v. 116, p. 309-315. 
GRIMM, E.C., 1992, Tilia 2 software. Illinois State Museum, Springfield, Illinois, U.S.A.

GROOT, J.J., 1966, Some observations on pollen grains in suspension in the estuary of the Delaware river: Marine Geology, v. 4, p. 409-416.

HARRISON, R.D., BANKA, R., THORNTON, I.W.B., SHANAHAN, M., and YAMUNA, R., 2001, Colonization of an island volcano, Long Island, Papua New Guinea, and an emergent island, Motmot, in its caldera lake. II. The vascular Flora: Journal of Biogeography, v. 28, p. 13111337.

HAVINGA, A.J., 1964, Investigation into the differential susceptibility of pollen and spores: Pollen et Spores, v. 6, p. 621-635.

HAVINGA, A.J., 1984, A 20-year experimental investigation into the differential corrosion susceptibility of pollen and spores in various soil types: Pollen et Spores, v. 26, p. 541-558.

HeDGES, J.I., and KEIL, R.G., 1995, Sedimentary organic matter preservation: an assessment and speculative synthesis: Marine Chemistry, v. 49, p. 81-115.

HofmanN, C.-C., 2002, Pollen distribution in sub-Recent sedimentary environments of the Orinoco Delta (Venezuela) - an actuo-palaeobotanical study: Review of Palaeobotany and Palynology, v. 119, p. 191-217.

HollowAY, R.G., 1989, Experimental mechanical pollen degradation and its application to Quaternary age deposits: The Texas Journal of Science, v. 41, p. 131-145. 
JACKSON, S.T., and LYFORD, M.E., 1999, Pollen dispersal models in Quaternary plant ecology: assumptions, parameters and prescriptions: The Botanical Review, v. 65, p. 39-75.

JACOBSON, G.L., and BRADSHAW, R.H.W., 1981, The selection of sites for palaeovegetational studies: Quaternary Research, v. 16, p. 80-96.

JÄGER, H., 2004, Facies dependence of spore assemblages and new data on sedimentary influence on spore taphonomy: Review of Palaeobotany and Palynology, v. 130, p. 121-140.

LAUER, W., 1978, Timberline studies in central Mexico: Arctic and Alpine Research, v. 10, p. 383-396.

LENHARDT, N., 2009, Volcaniclastic successions of the southern edge of the Transmexican Volcanic Belt: evidence for the Miocene plate reorganisation in Central America (Morelos, Mexico): Unpublished Ph.D. Thesis, Darmstadt University of Technology, Germany, 141 p. URL: http://tuprints.ulb.tu-darmstadt.de/1405/

LENHARDT, N., and GÖTZ, A.E., 2011, Volcanic settings and their reservoir potential: an outcrop analogue study on the Miocene Tepoztlán Formation, Central Mexico: Journal of Volcanology and Geothermal Research, v. 204, p. 66-75.

Lenhardt, N., Martinez-Hernandez, E., Götz, A.E., Hinderer, M., Hornung, J., TorRES-AlVARADO, I.S., and KeMPE, S., 2006, Palaeoenvironmental Reconstruction of the Miocene Tepoztlán Formation (Central Mexico): Preliminary Results of Palynological Investigations. in ESPINASA-PERENA, R., and PINT, J., eds., Proceedings of the X, XI, and XII international symposia on volcanospeleology. AMCS Bulletin, v. 19, p. 158-161. 
Lenhardt, N., Herrmann, M., Mosbrugger, V., and Hinderer, M., 2008. Palynology of the Tepoztlán Formation, Central Mexico - palaeoenvironmental and palaeoclimatological implications: Terra Nostra 2008/2, 12th International Palynological Congress IPC-XII/IOPCVIII, Bonn, Abstract Volume, p. 162.

Lenhardt, N., BÖHnel, H., Wemmer, K., Torres-Alvarado, I.S., Hornung, J., and HINDERER, M., 2010, Petrology, magnetostratigraphy and geochronology of the Miocene volcaniclastic Tepoztlán Formation: implications for the initiation of the Transmexican Volcanic Belt (Central Mexico): Bulletin of Volcanology, v. 72, p. 817-832.

Lenhardt, N., Hornung, J., Hinderer, M., BöHnel, H., TORRES-Alvarado, I.S., and TRAUTH, N., 2011, Build-up and depositional dynamics of an arc front volcaniclastic complex: the Miocene Tepoztlán Formation (Transmexican Volcanic Belt, Central Mexico): Sedimentology, v. 58, p. 785-823.

Lenhardt, N., BöHnel, H., Hinderer, M., and Hornung, J., 2013, Paleocurrent direction measurements in a volcanic setting by means of anisotropy of magnetic susceptibility: A case study from the Lower Miocene Tepoztlán Formation (Transmexican Volcanic Belt, Central Mexico): Sedimentary Geology, v. 290, p. 1-14.

LENTFER, C., and TORRENCE, R., 2007, Holocene volcanic activity, vegetation succession, and 847 ancient human land use: Unraveling the interactions on Garua Island, Papua New Guinea: Review of Palaeobotany and Palynology, v. 143, p. 83-105. 
LOWE, J.J., 1982, Three Flandrian pollen profiles from the Teith Valley, Perthshire, Scotland.

II. Analysis of deteriorated pollen: New Phytologist, v. 90, p. 371-385.

LUNA, V.I., AlMEIDA, L., VILlERS, L., and LORENZO, L., 1988, Reconocimiento florístico y consideraciones fitogeográficas del bosque mesófilo de montaña de Teocelo, Veracruz:

Boletín de la Sociedad Botánica de México, v. 48, p. 35-63.

LUNA, I., AlmEIDA, L., and LlORENTE, J., 1989, Florıstica y aspectos fitogeograficos del bosque mesofilo de montana de las canadas de Ocuilan, Estados de Morelos y Mexico : Anales Instituto Biología, Universidad Nacional Autónoma de México, Serie Botánica, v. 59, p. $63-87$.

LunA, V.I., OCEGUEDA, C.S., and AlCÁNTAR, A.O., 1994, Florística y notas biogeográficas del bosque mesófilo de montaña del municipio de Tlanchinol, Hidalgo, México : Anales del Instituto de Biología, Universidad Nacional Autónoma de México, Serie Botánica, v. 65(1), p. $31-62$.

LunA-VeGA, I., AlmEIDA-LEÑERO, L., and LlorentebousQuets, J., 1989, Florística y aspectos fitogeográficos del bosque mesófilo de montaña de las cañadas de Ocuilan, Estados de Morelos y México : Anales del Instituto de Biología, Universidad Nacional Autónoma de México, Serie Botánica, v. 59(1), p. 63-87.

MaCGinITIE, H.D., 1953, Fossil plants of the Florissant Beds, Colorado: Carnegie Institution of Washington Contributions to Paleontology, v. 559, p. 1-198. 
MACHAIN-CASTILlO, M., 1985, Ostracode biostratigraphy and paleoecology of the Pliocene of the Isthmian salt basin, Veracruz, Mexico: Tulane Studies in Geology and Paleontology, v. 19, p. 123-139.

Marchant, R., Almeida, L., Behling, H., Berrio, J.C., Bush, M., Cleef, A., Duivenvoorden, J., KAPPElle, M., De Oliveira, P., De OliveirA-Filho, A.T., LoZANOGarcía, S., Hooghiemstra, H., Ledru, M.-P., Ludlow-Wiechers, B., MARKGRAF, V., Mancini, V., PAez, M., Prieto, A., Rangel, O., and Salgado-Labouriau, M.L., 2002, Distribution and ecology of parent taxa of pollen lodged within the Latin American Pollen Database: Review of Palaeobotany and Palynology, v. 121, p. 1-75.

Márquez, A., Verma, S., Anguita, F., Oyarzun, R., and Brandle, J., 1999, Tectonics and volcanism of Sierra Chichinautzin: Extension at the front of the central transmexican volcanic belt: Journal of Volcanology and Geothermal Research., v. 93, p. 125-150.

MARTínEZ-HERnÁNDEZ, E., and RAMÍREZ-ARRIAGA, E., 1999, Palinoestratigrafía de la región de Tepexi de Rodríguez, Puebla, implicaciones cronoestratigráficas: Revista Mexicana de Cienias Geológicas, v. 16(2), p. 187-207.

Mayorga, S.R., LunA, V.I., and AlCÁnTARA, A.O., 1998, Florística del Bosque mesófilo de montaña de Molocotlán, Molango-Xochicoatlán, Hidalgo, México: Boletín de la Sociedad Botánica de México, v. 63, p. 101-119.

MELIA, M.B., 1984, The distribution and relationship between palynomorphs in aerosols and deep-sea sediments off the coast of northwest Africa: Marine Geology, v. 58, p. 345-371. 
MEYER, H.W., 2003, The fossils of Florissant: Smithsonian Institution Press, Washington D.C., $258 \mathrm{p}$.

MirAndA, F., 1947, Estudios sobre la vegetación de México V. Rasgos de la vegetación en la cuenca del río de las Balsas: Revista de la Sociedad Mexicana de Historia Natural, v. 8(1-4), p. $95-114$.

Miranda, F., and HernandeZ-X., 1963, Los tipos de vegetacion de Mexico y su clasificacion: Boletín de la Sociedad Botánica de México, v. 28, p. 29-179.

MULLER, J., 1959, Palynology of recent Orinoco delta and shelf sediments:

Micropalaeontology, v. 5, p. 1-32.

PALACIOS, C.R., and RZEDOWSKI, J., 1993, Estudio palinológico de las floras fósiles del Mioceno inferior y principios del Mioceno medio de la región de Pichucalco, Chiapas, México: Acta Botánica Mexicana, v. 24, p. 1-96.

PRENTICE, I.C., 1985, Pollen representation, source area and basin size: towards a unified theory of pollen analysis: Quaternary Research, v. 23, p. 76-86.

Ramirez-Arriaga, E., Martinez-Hernández, E., Flores-Olvera, H., Ochotorena, H., and PRÁMPARO, M.B., 2008. Correlation of the Late Eocene-Early Oligocene Izúcar de Matamoros evaporates (Cuayuca Formation) in Mexico based on parsimony analysis of endemicity: Palynology, v. 32, p. 231-252. 
RAYNOR, G.S., HAYES, J.V., and OGDEN, E.C., 1974, Mesoscale transport and dispersion of airborne pollens. Journal of Applied Meteorology, v. 13, p. 87-95.

RICHARDS, P.W., 1996, The tropical rain forest; an ecological study: $2^{\text {nd }}$ ed., Cambridge Univ. Press, Cambridge.

Ross, C.S., and SMITH, R.L., 1961, Ash-flow tuffs. Their Origin, Geological Relations and Identification: U.S. Geological Survey Professional Paper, v. 366, 81 p.

RZEDOWsKi, J., 1978, Vegetación de México: Editiones Limusa, 432 p.

RZEDOWSKI, J., 1996, Análisis preliminar de la flora vascular de los bosques mesófilos de montaña de México: Acta Botánica Mexicana, v. 35, p. 25-44.

SANGSTER, A.G., and DALE, H.M., 1961, A preliminary study of differential pollen grain preservation: Canadian Journal of Botany, v. 39, p. 35-43.

SANGSTER, A.G., and DALE, H.M., 1964, Pollen grain preservation of underrepresented species in fossil spectra: Canadian Journal of Botany, v. 42, p. 437-449.

SCHEIHING, M.H., and PFEFFERKORN, H.W., 1984, The taphonomy of land plants in the Orinoco delta: A model for the incorporation of plant parts in clastic sediments of Late Carboniferous age of Euramerica: Review of Palaeobotany and Palynology, v. 41, p. 205240. 
SCHOFIELD, J.E., EDWARDS, K.J., and MCMulLEN, J.A., 2007, Modern pollen-vegetation relationships in subarctic southern Greenland and the interpretation of fossil pollen data from the Norse landnám: Journal of Biogeography, v. 34, p. 473-488.

SHELFORD, V.E., 1963, The ecology of North America: University of Illinois Press, Urbana, $153 \mathrm{p}$.

SIEBE, C., and MACÍAS, J.L., 2004, Volcanic hazards in the Mexico City metropolitan area from eruptions at Popocatépetl, Nevado de Toluca, and Jocotitlán stratovolcanoes and monogenetic scoria cones in the Sierra Chichinautzin Volcanic Field: Penrose Field Guide 1, p. $1-77$.

Siebe, C., RodríGuez-Lara, V., SchaAf, P., and Abrams, M., 2004, Geochemistry, Sr-Nd isotope composition, and tectonic setting of Holocene Pelado, Guespalapa and Chichinautzin scoria cones, south of Mexico City: Journal of Volcanology and Geothermal Research, v. 130(3-4), p. 197-226.

SPARKS, R.S.J., 1976, Grain size variations in ignimbrites and implications for the transport of pyroclastic flows: Sedimentology, v. 23, p. 147-188.

STANLEY, E.A., 1966, The problem of reworked pollen and spores in marine sediments:

Marine Geology, v. 4, p. 397-408.

STIX, E., 1975, Pollen-und Sporengehalt der Luft im Herbst über dem Atlantik: Oecologia, v. 18 , p. $235-242$. 
STREEL, M., and BLESS, M.J.M., 1980, Occurrence and significance of reworked palynomorphs: Mededelingen van de Rijks Geologische Dienst, v. 32(10), p. 69-80.

Sugita, S., GAILlard, M.-J., and BroströM, A., 1999, Landscape openness and pollen records: a simulation approach: The Holocene, v. 9, p. 409-421.

TAGAwA, H., 1964, A study of the volcanic vegetation in Sakurajima, southwest Japan: Memoirs of the Faculty of Science, Kyushu University, Series E, Biology, v. 3, p. 166-288.

TAGGART, R.E., and CROSS, A.T., 1974, History of vegetation and paleoecology of upper Miocene Sucker Creek beds of eastern Oregon: Birbal Sahni Institute (Lucknow) Special Publication, v. 3, p. 125-132.

TAgGaRT, R.E., and Cross, A.T., 1980, Vegetation change in the Miocene Sucker Creek flora of Oregon and Idaho: a case study in paleosuccession, in DILCHER, D.L., and TAYLOR, T.N., eds., Biostratigraphy of fossil plants: Dowden, Hutchinson, and Ross, Inc., Stroudsburg, Pennsylvania, p. 185-210.

TAGGART, R.E., and CROSS, A.T., 1982, Effects of periodic volcanism on Miocene vegetation distribution in eastern Oregon and western Idaho: Proceedings of the Third North American Paleontology Convention, Montreal: Toronto, Business and Economic Service Ltd., v. 2, p. $535-540$.

TAgGart, R.E., and Cross, A.T., 1990, Plant successions and interruptions in Miocene volcanic deposits, Pacific Northwest, in LOCKLEY, M.G., and RICE, A., eds., Volcanism and Fossil Biotas: GSA Special Publication, v. 244, p. 57-68. 
TIPPING, R., 1995, Holocene landscape change at Carn Dubh Dubh, near Pitlochry, Perthshire: Journal of Quaternary Science, v. 10, p. 59-75.

TRAVERSE, A., 1992, Organic fluvial sediment: palynomorphs and palynodebris in the Lower Trinity River, Texas: Annals of the Missouri Botanical Garden, v. 79, p. 110-125.

TwEDDLE, J.C., and EDWARDS, K.J., 2010, Pollen preservation zones as an interpretative tool in Holocene palynology: Review of Palaeobotany and Palynology, v. 161(1-2), p. 59-76.

UmbanhowaR, C.E., JR., and MCGRATH, M.J., 1998, Experimental production and analysis of microscopic charcoal from wood, leaves and grasses: The Holocene, v. 8(3), p. 341-346.

VAN DER ZWAN, C.J., and VAN VEEN, P.M., 1978, The Devonian-Carboniferous transition sequence in southern Ireland: integration of palaeogeography and palynology: Palinologia, v. 1, p. $469-479$.

VIDAL, G., 1988, A palynological preparation method: Palynology, v. 12, p. 215-220.

WiLmhurst, J.M., and MCGlone, M.S., 2005, Corroded pollen and spores as indicators of changing lake sediment sources and catchment disturbance: Journal of Paleolimnology, v. 34, p. 503-517.

WILSON, C.J.N., and WALKER, G.P.L., 1982, Ignimbrite depositional facies: the anatomy of a pyroclastic flow: Journal of the Geological Society of London, v. 139, p. 581-592. 
Wolfe, J.A., and ScHORN, H.E., 1989, Paleocologic, Paleoclimatic, and Evolutionary

Significance of the Oligocene Creede Flora, Colorado: Paleobiology, v. 15(2), p. 180-198.

WoODS, R.D., 1955, Spores and pollen — a new stratigraphic tool for the oil industry:

Micropaleontology, v. 1, p. 368-375. 